\title{
論謱及寄書
}

各種電燈器具の配光曲線

\section{Light Distribution Curves of Various Lighting Fixtures.}

\author{
正會員關重 廣 \\ 准 員 北 村 品 三
}

（東京電柲粎式會融研笕所）

私たちが東京電氮會社破究所に於て照吸に關する研究資料として測定いれしまし

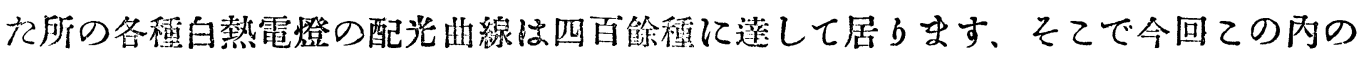
代表的のもの約百狳種を拔萃してて〉に發表する次第でありむす。

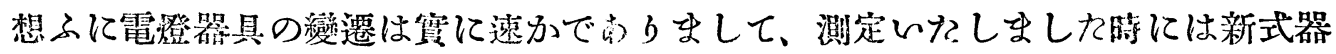
具と思つて居りむしたものでも唯今ではるはやすねれからつて居るものも可成あり ぬす。從つてての曲線集にのせてある器具の全部が過去のものとなつて貫用に供せ られない時代の棑るのも遠くないかも知几すせん、关故此曲線集は唯大正七年頃 から同十二年に至るむでの五六年間に主として使用せられて居つた器具の测定結果 である事を御承知愿したいのでありむす。

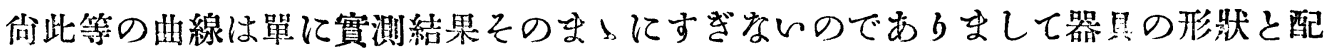
光との關係などの事柄については大正十一年六月發行の照明學會雜誌中の「各種電

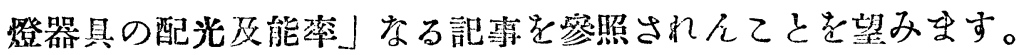

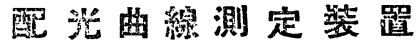

配光曲線の測定には普通の光度計の外に特殊の回轉装置が必要であります、第一

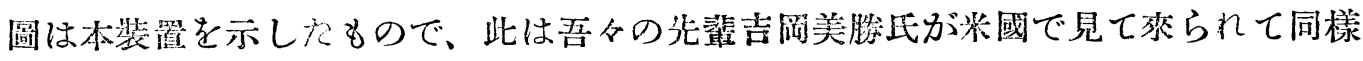
なものを設計製作されれものでありるす、中央につり下げられれるのはクレーンで あらなしてその雨端にルンマーブロジューン對照型のホトヌーターーツドを有して 居りむす。

右倒に示されてあるのは小型器具の湘定に使用するるので鏡と器具とが闹時に回 轉いたしなす、左側にあるのは大型器具例へげ等間接器具の如きるのを测定する裝 置で、器具は動かずに二枚の鏡が回輽いたします、!回轉面は紙面に直角なる垂直本 


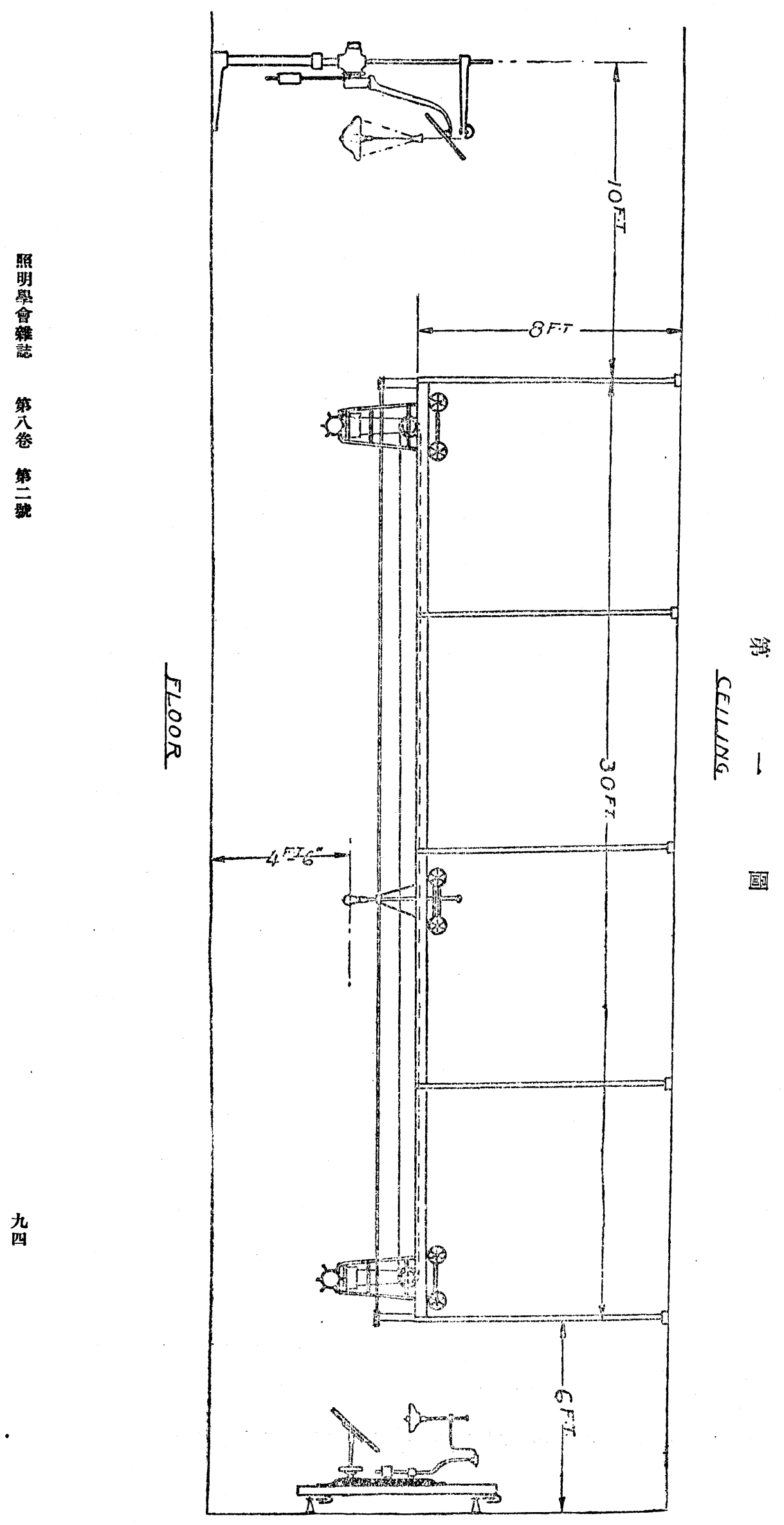




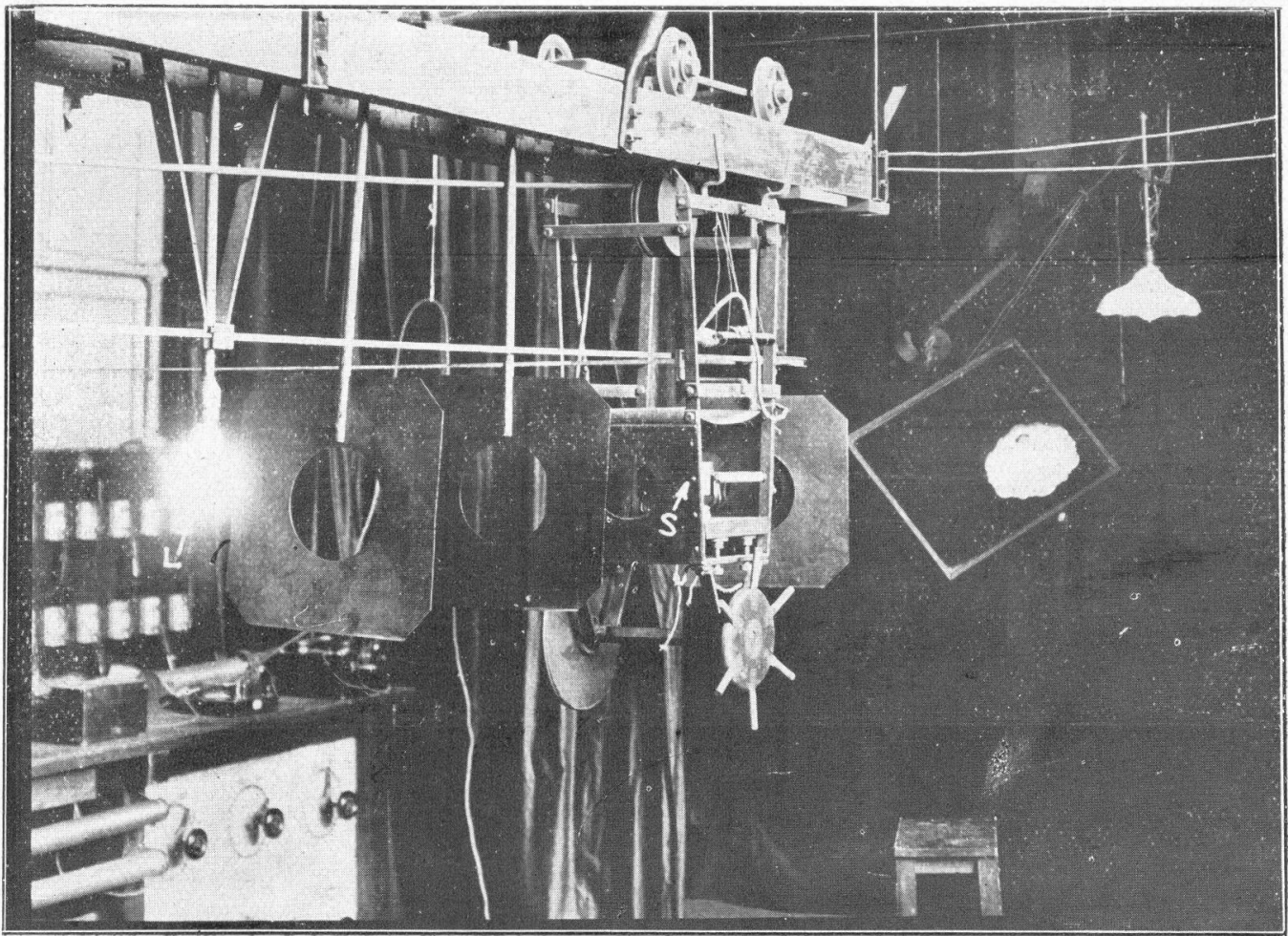

第 三圖

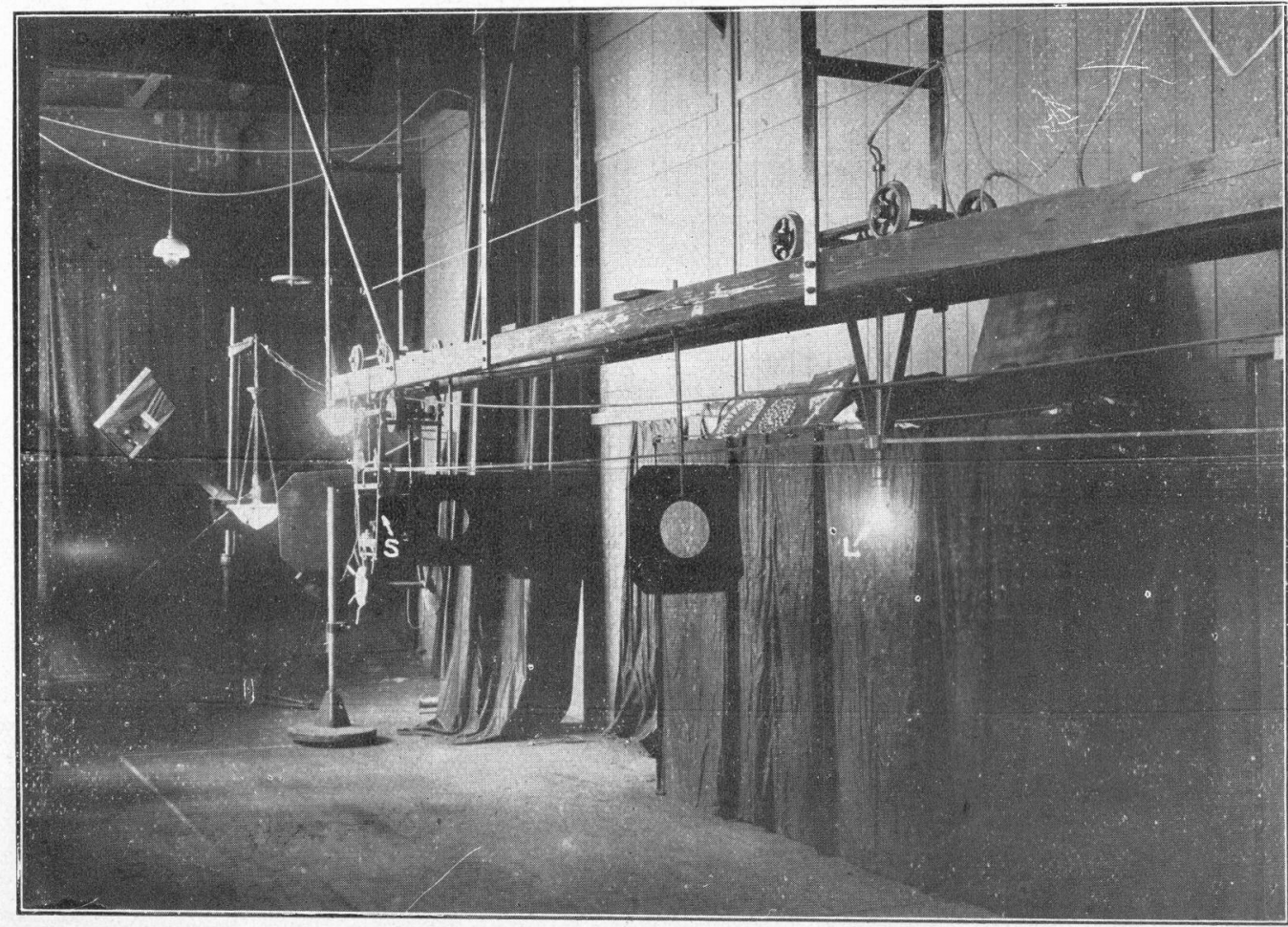




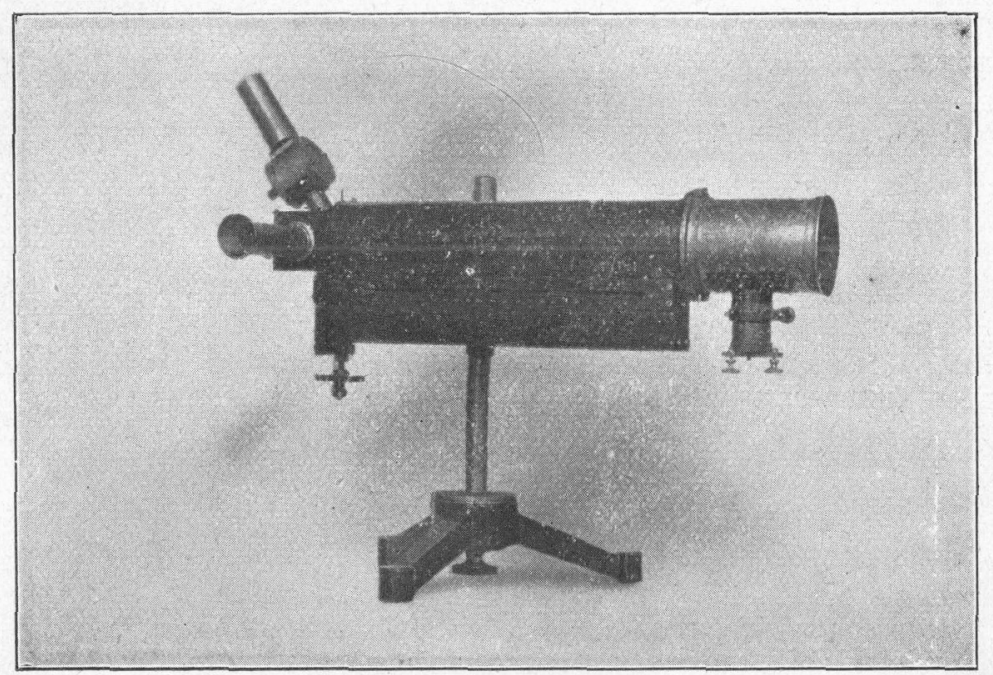


面でありむす）ての場合には左右の同角度の方向の光度が重なり合つてへッドに來 ますから其値の本分が左右の本均值と学りむす。

標準電球は中央のクレーンの下にあつて雨へッドの下にある車を動かすてとによ つて左右に移動されます、乙の標準電球は左右の装置に共通のもの故乙の兩裝置を 同時に使用するてとは出爽ないのでありむす、乙のクレーンの全長は五間で左右兩 装置を含めてての配光測定装置の全長は約八間でありむす。

せた投光器の如き光柱を有するものつ配光を测定するにはフランッシュミッド製 の携帶用光度計を使用し充分遠距離に於て测定いたしむしれ。

第二圖及第三圖は前訅二種の回轉装置の寫悬でありむして、Lは標準電球、 $\mathrm{S}$ はへッドでありむす、また第四圖は携帶用光度計であります。

\section{毣 球 乙 器 具}

ての曲線集にのせせしね所の器具と電球との組合せはをるべく適當と思はるつも のゆみ探用し、例へば $\mathrm{C}$ 電球にP-1笠をつけれ場合の如さ不適賞な組合せは探用し せせんでしん、電球はすべて東京電氯會㼛製マッダランプを使用しましれ、此內 $\mathrm{C}$ 電球はすべてワットを以て大さを表はしむした、ワットと球面燭光との關係は製作 法の進步につれて色筱りむすが此曲線集にはすべて第一表の如さ場合を探用しま しれ。

$\mathrm{B}$ 電球並に C 電球のルーメ゙ン數も第一表の如く探りむしれ。

第

表

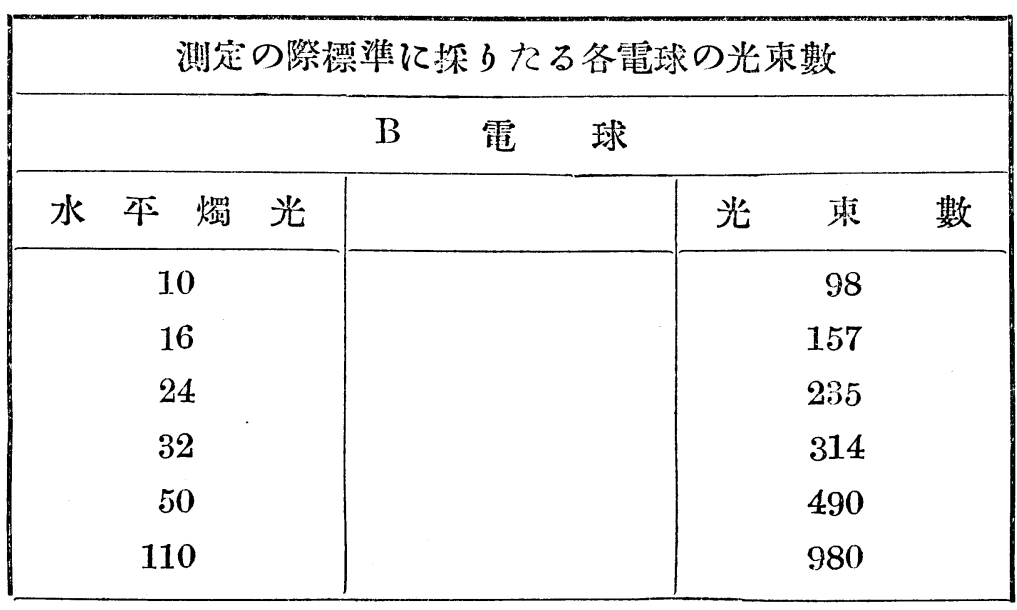




\begin{tabular}{|c|c|c|c|c|c|c|c|c|}
\hline \multirow[b]{2}{*}{7} & \multirow[b]{2}{*}{ ツ } & \multicolumn{2}{|r|}{$\mathrm{C}$} & 電 & \multicolumn{2}{|l|}{ 球 } & \multirow[b]{2}{*}{ 束 } & \multirow[b]{2}{*}{ 數 } \\
\hline & & ト & 球 & 面 燭 & 光 & 光 & & \\
\hline & 20 & & \multicolumn{3}{|c|}{12.50} & \multicolumn{3}{|c|}{157} \\
\hline & 30 & & \multicolumn{3}{|c|}{20,40} & \multicolumn{3}{|c|}{256} \\
\hline & 40 & & \multicolumn{3}{|c|}{28.55} & \multicolumn{3}{|c|}{359} \\
\hline & 60 & & \multicolumn{3}{|c|}{50.00} & \multicolumn{3}{|c|}{628} \\
\hline & 80 & & \multicolumn{3}{|c|}{72,7} & \multicolumn{3}{|c|}{913} \\
\hline & 100 & & \multicolumn{3}{|c|}{100} & \multicolumn{3}{|c|}{1256} \\
\hline & 150 & & \multicolumn{3}{|c|}{150} & \multicolumn{3}{|c|}{1885} \\
\hline & 200 & & \multicolumn{3}{|c|}{200} & \multicolumn{3}{|c|}{2510} \\
\hline & 250 & & \multicolumn{3}{|c|}{250} & \multicolumn{3}{|c|}{3140} \\
\hline & 300 & & \multicolumn{3}{|c|}{316} & \multicolumn{3}{|c|}{3970} \\
\hline & 400 & & \multicolumn{3}{|c|}{445} & \multicolumn{3}{|c|}{5590} \\
\hline & 500 & & \multicolumn{3}{|c|}{588} & \multicolumn{3}{|c|}{7390} \\
\hline & 750 & & \multicolumn{3}{|c|}{938} & \multicolumn{3}{|c|}{11780} \\
\hline & 1000 & & \multicolumn{3}{|c|}{1335} & \multicolumn{3}{|c|}{16750} \\
\hline & 1500 & & \multicolumn{3}{|c|}{2000} & & 25100 & \\
\hline
\end{tabular}

\section{分 類}

曲線は百づ〉の我番號によb次の如く分類いたしぬした。

1一、電 球

101 一間接照时器具

201一。留閔接照明器具

301一、少間器具及室內用グローブ

401 一、硝子、䋊、椎、製反射笠

501 一、镜面反射笠

601 一金屬反射笠

景 701一、屋外用グローブ

801 一特殊器具

圖面說明

各器具の名穫は一般的商品名をからげるてとにいたしむしたが、名の不明なるの は形狀によb腾手につけてちきむした故、常に有側の器具の圖を對照されんてとを 望みます。 
附號は次の如くでありむす。

B、具空タングスラン電球

C. 死斯望䒧タングスッ゙ン電球

c. 燭 治

w. ワット

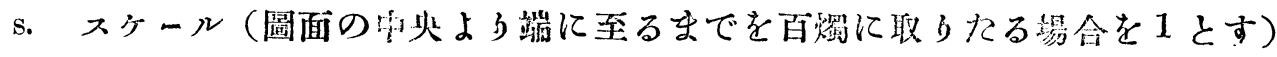

L. 器具に附しれ場合の總ルーメン數

E. 器具の能率 ( I と電球自身のルーメン繁との百分比)

S.R.F. 球面換算卒

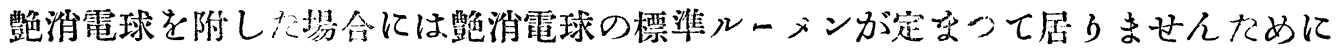

S.も む.も揭げないてとにいわっむしね。

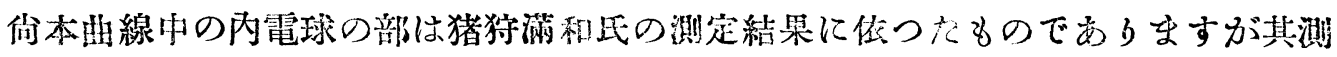

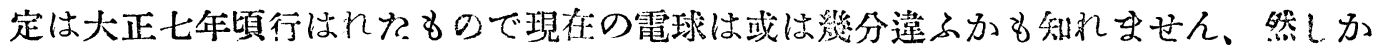

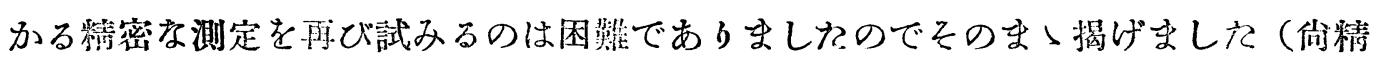
しくは照明學會維誌第三管第二號の㒂狩理學士の諭文「白熱電球球面換算率の测定」 を御參照下さい)

せた同じ茄子型與空タングスラン電球でも5 蠋と 100 㷎では幾分配光の具合もち がひすすが簡單にするれめ一所に本均してしまいむしれ、然し大體の傾向はわかる と思とさす。

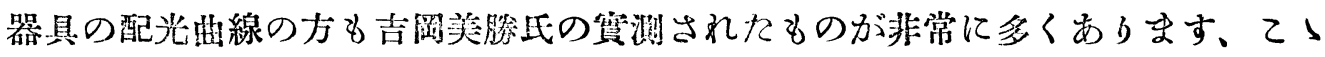
に猪独、吉阔雨先輩に對し梁く謝䈍を表します。 

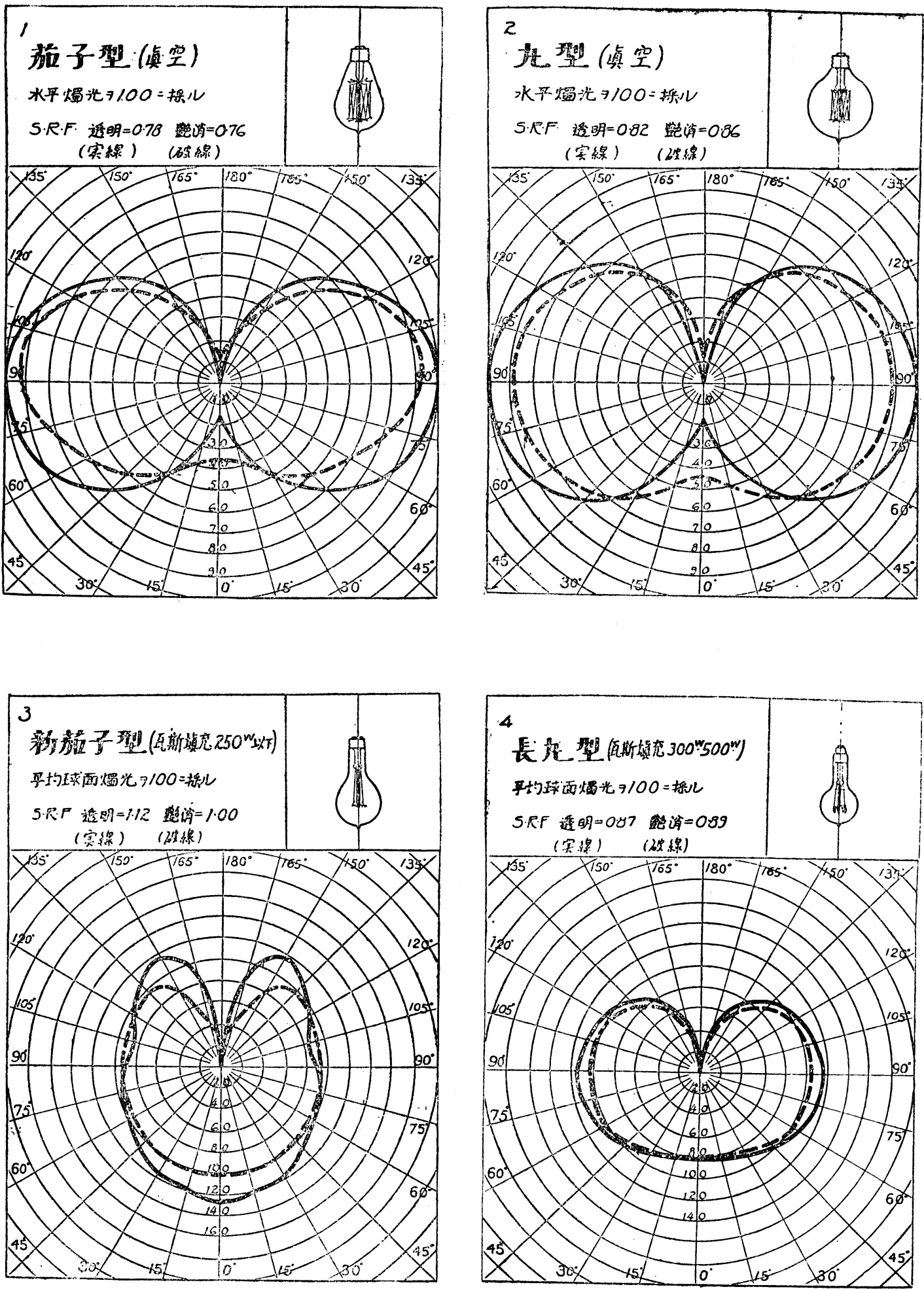

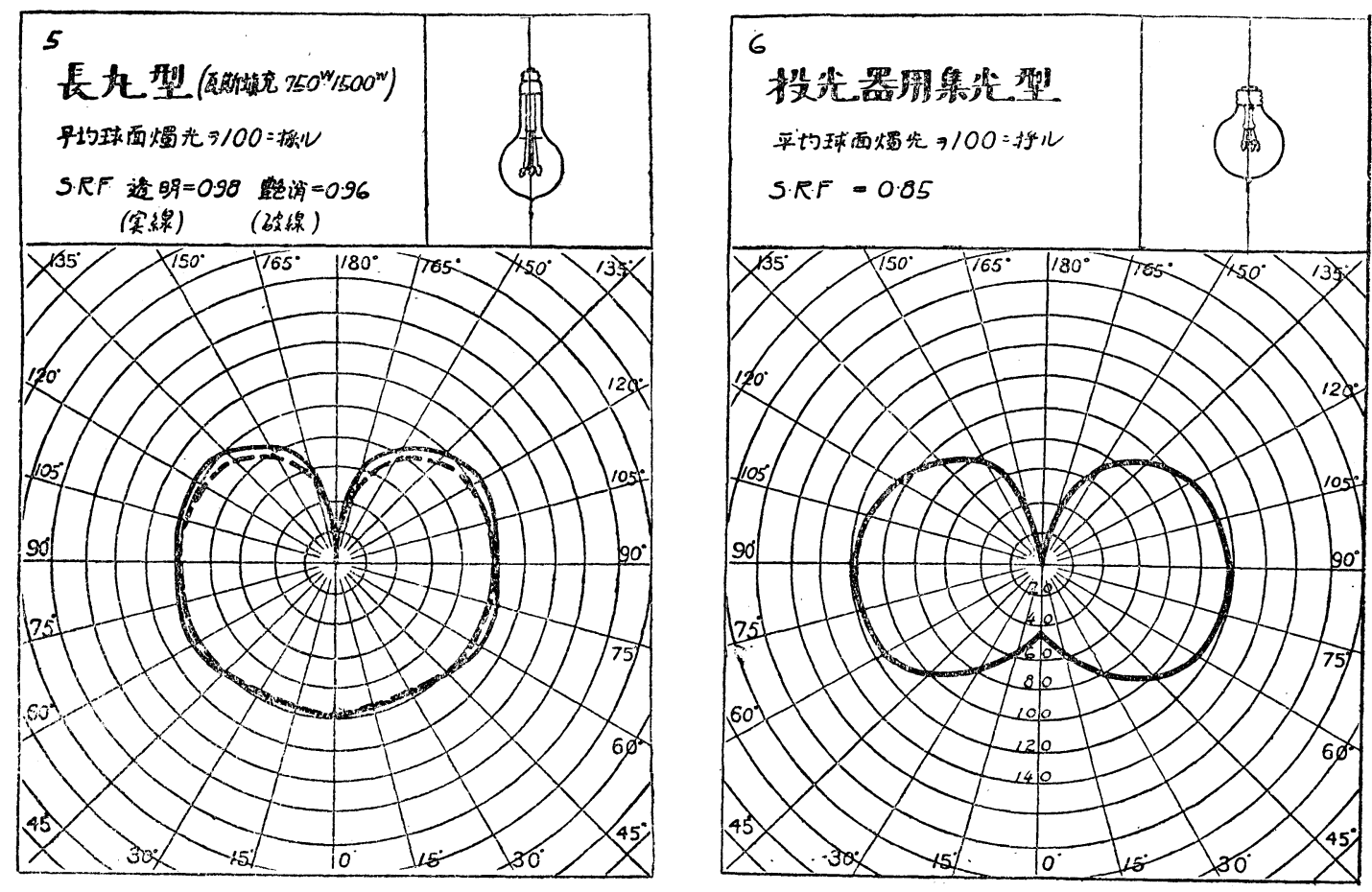

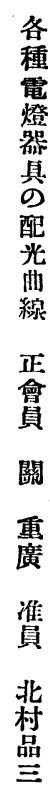

間 接 照 明 器 具
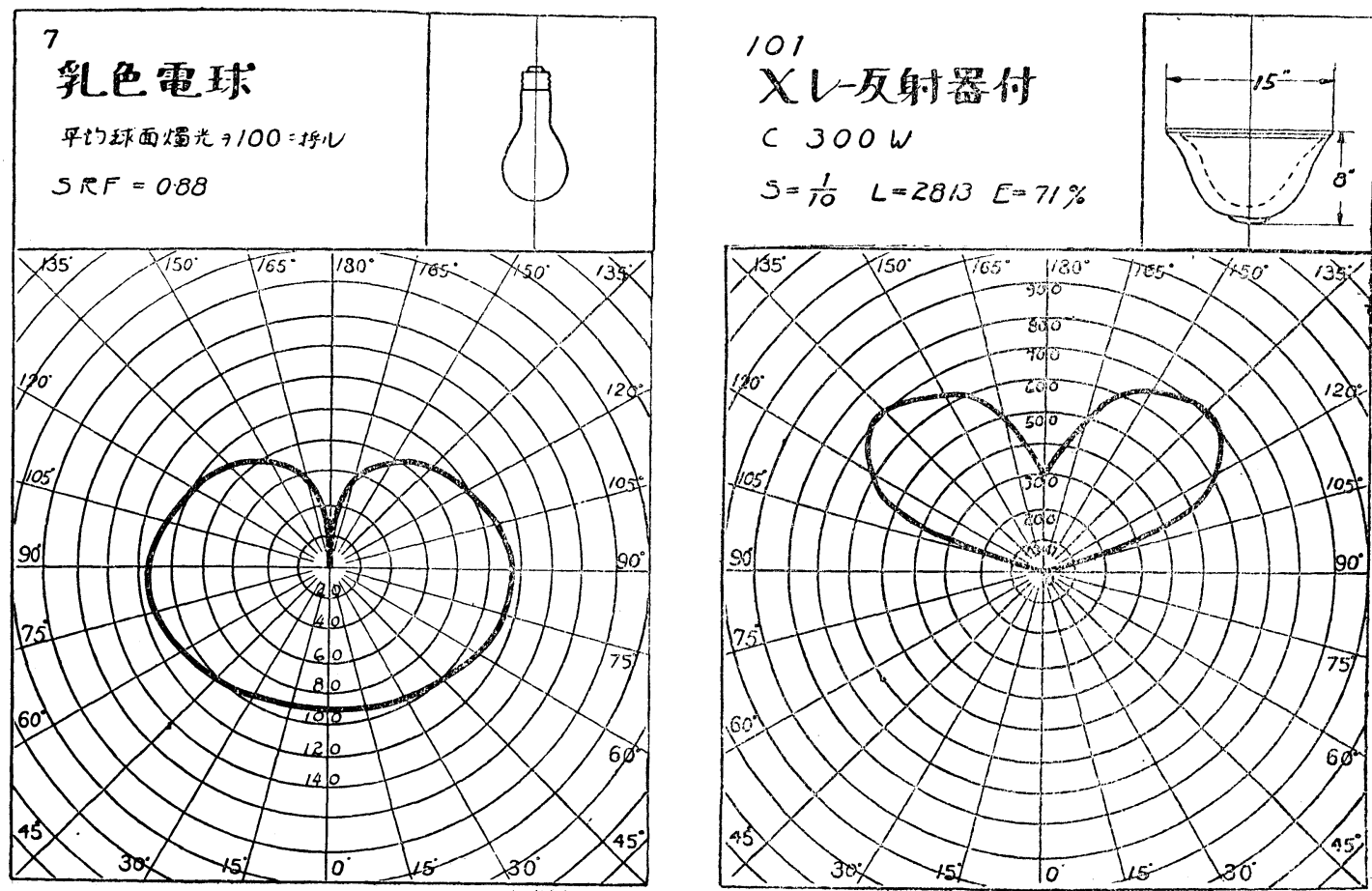


\section{坐間接照明器 具}
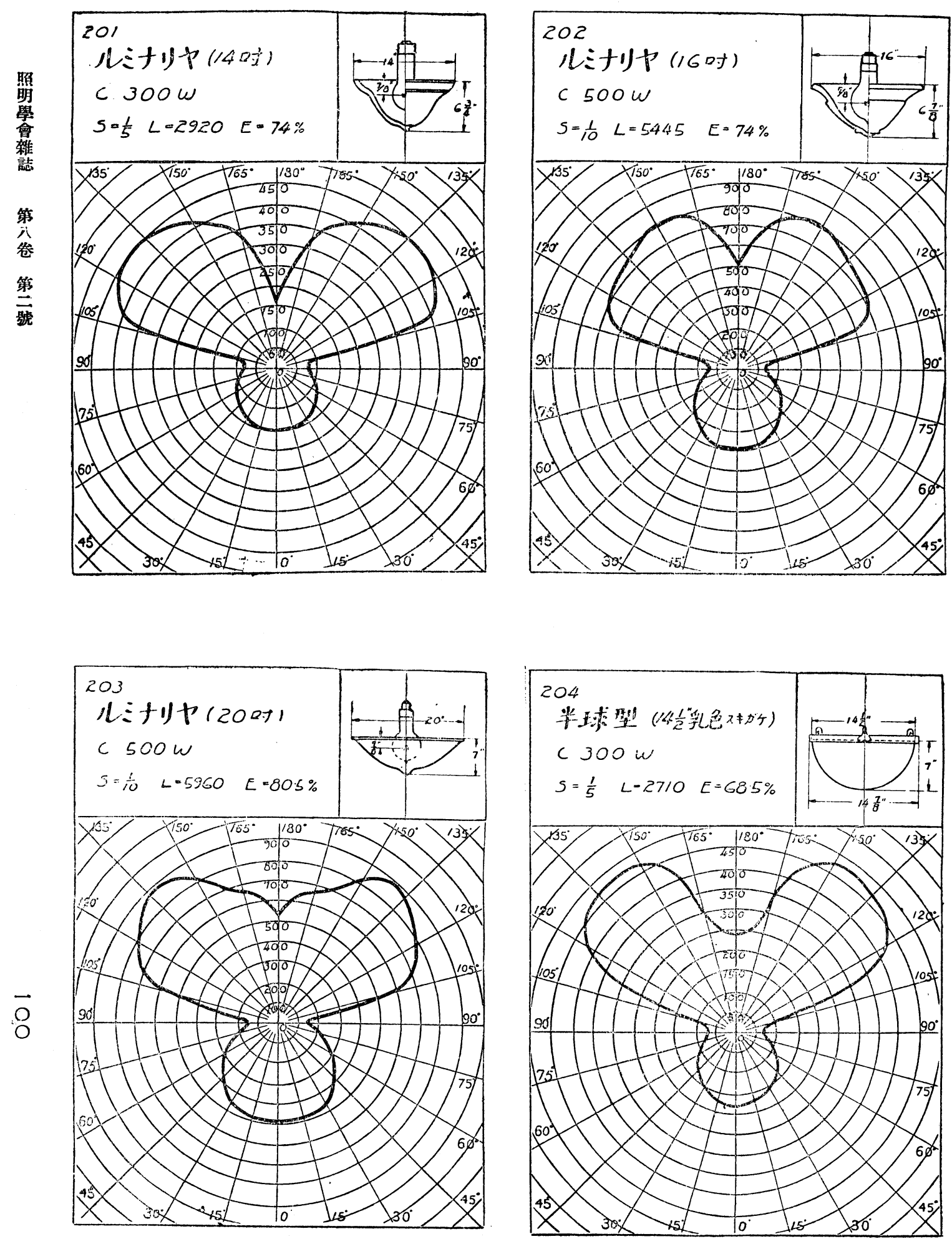

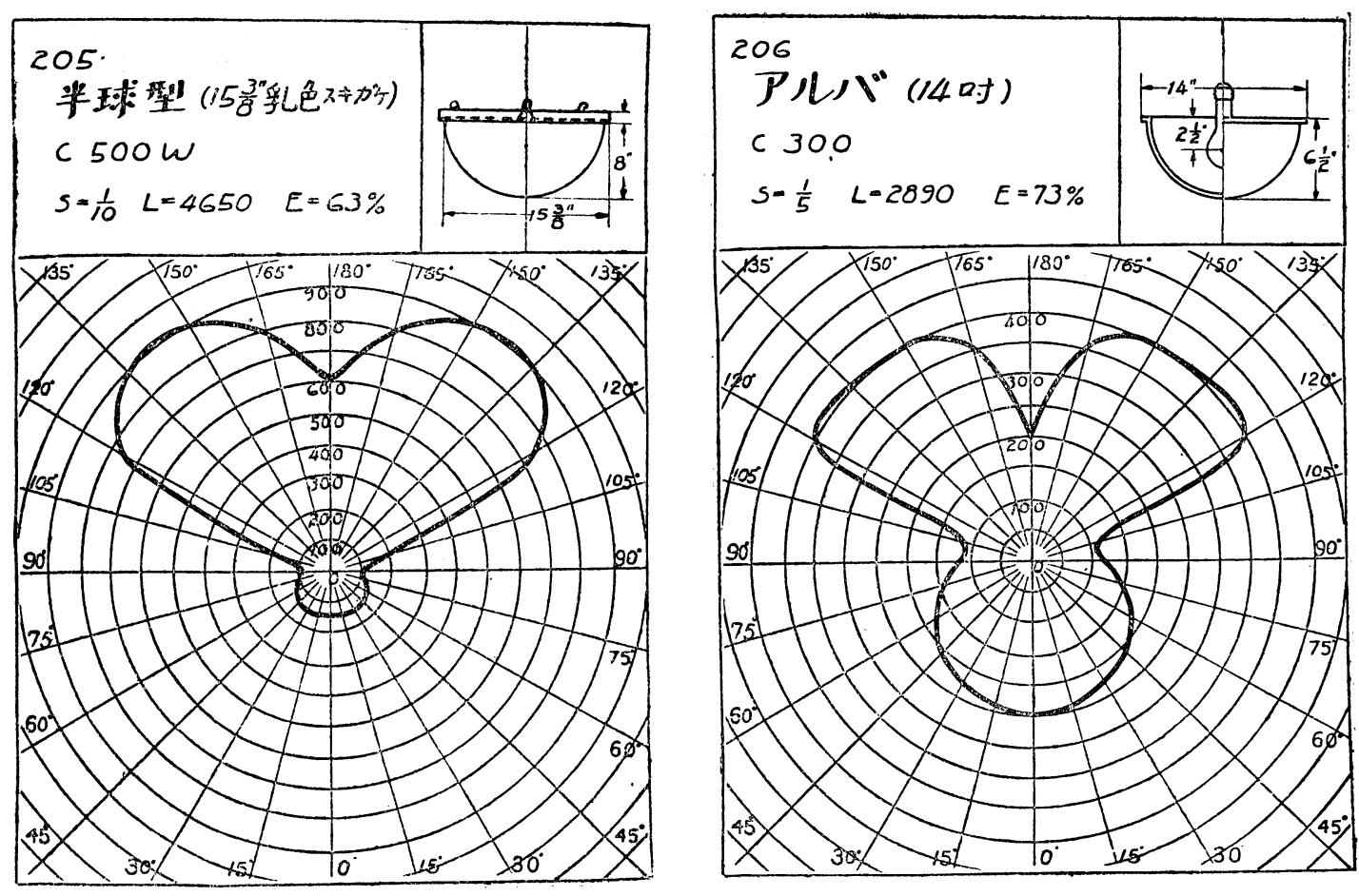

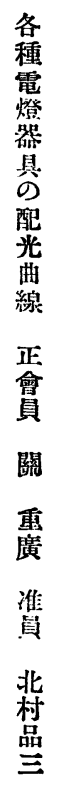
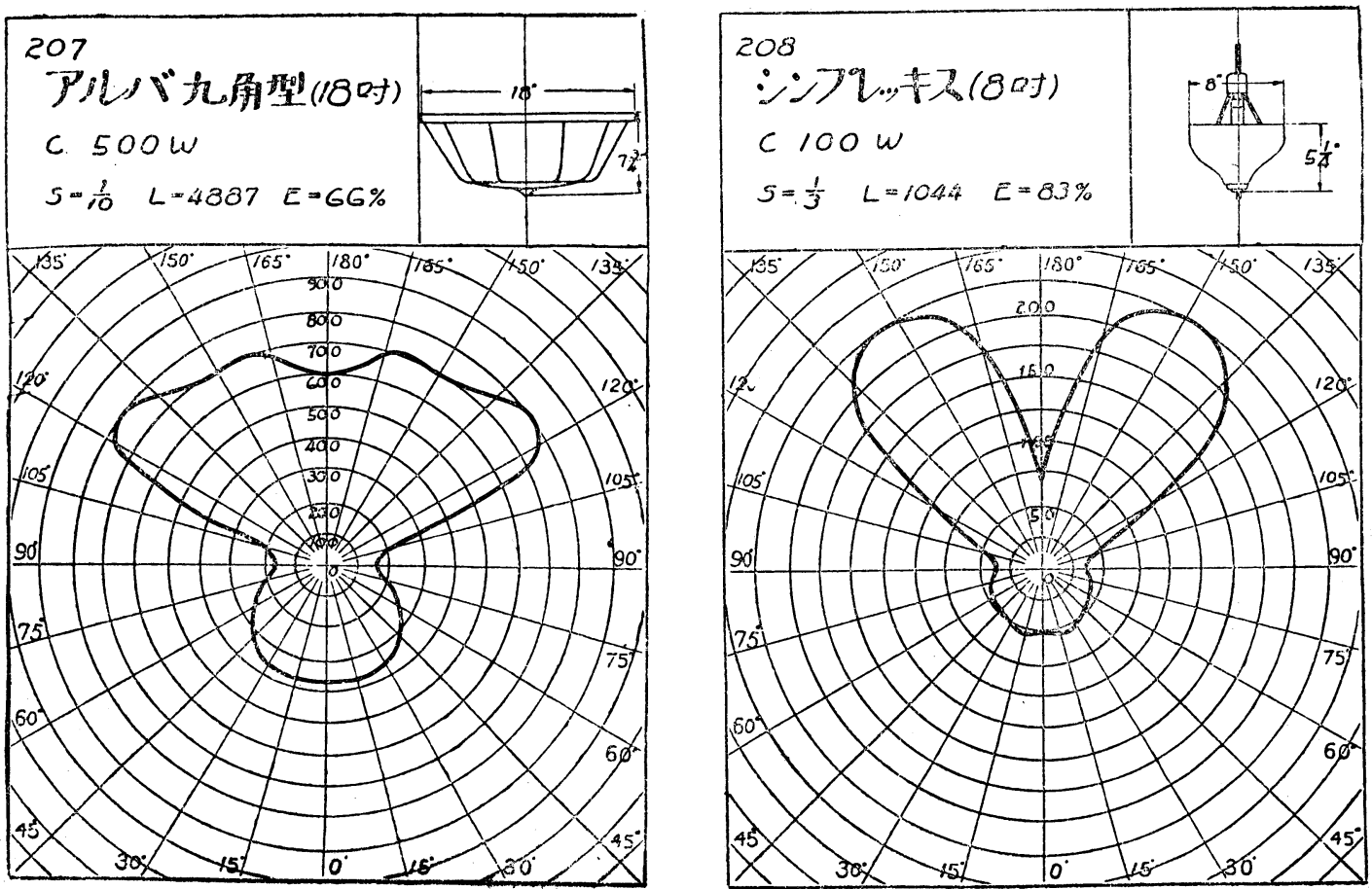

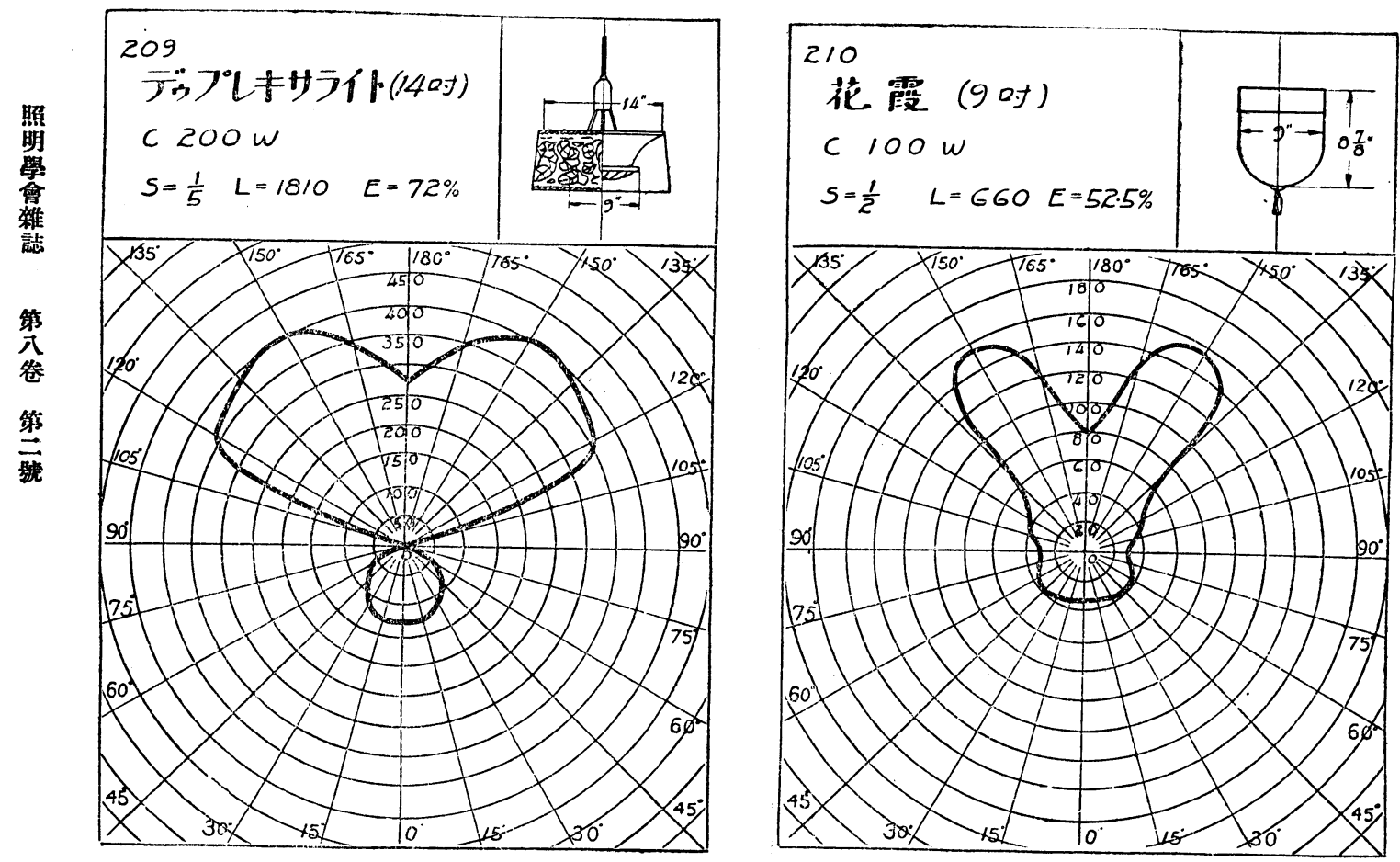

牛圍器具並室內用グローブ
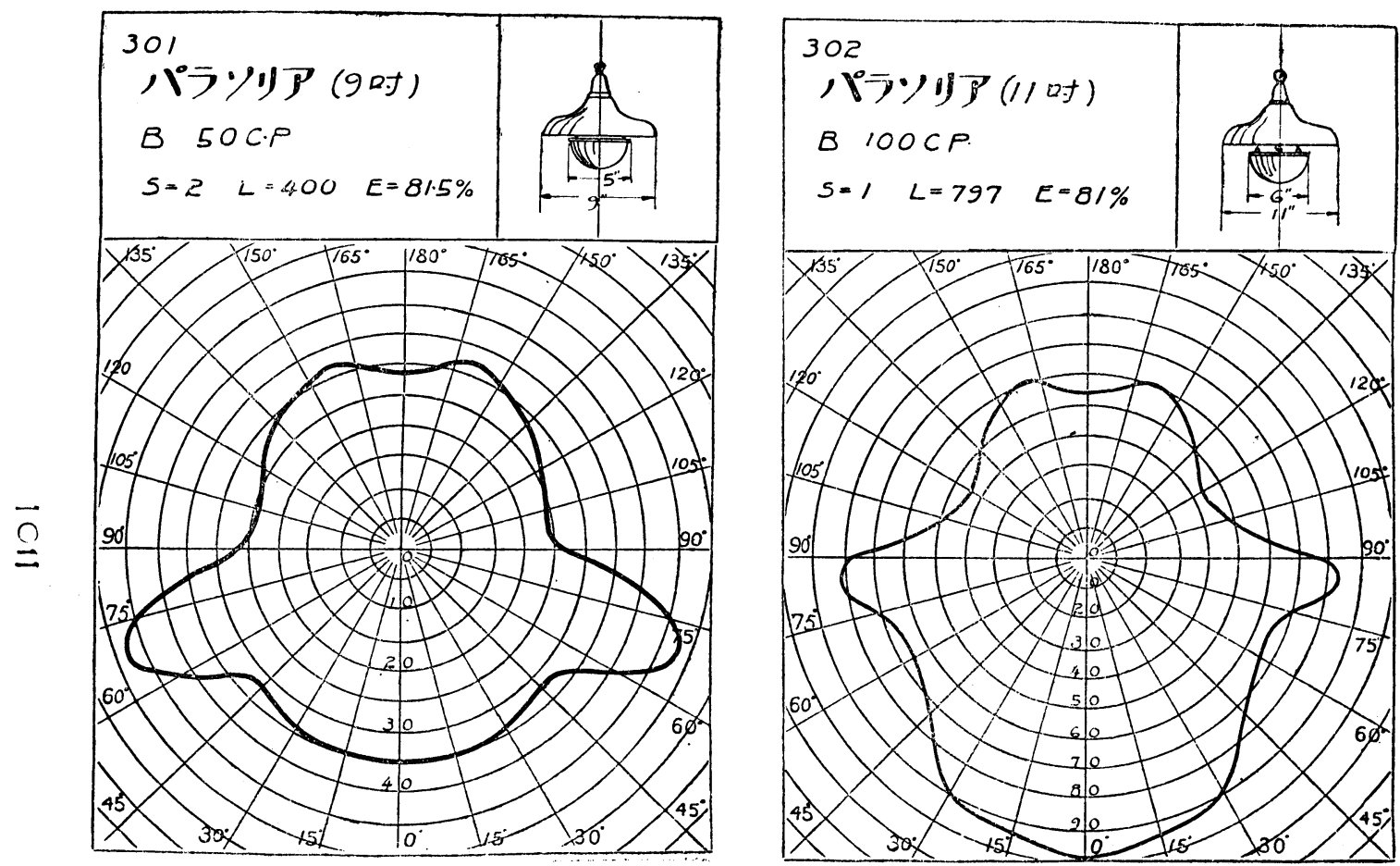

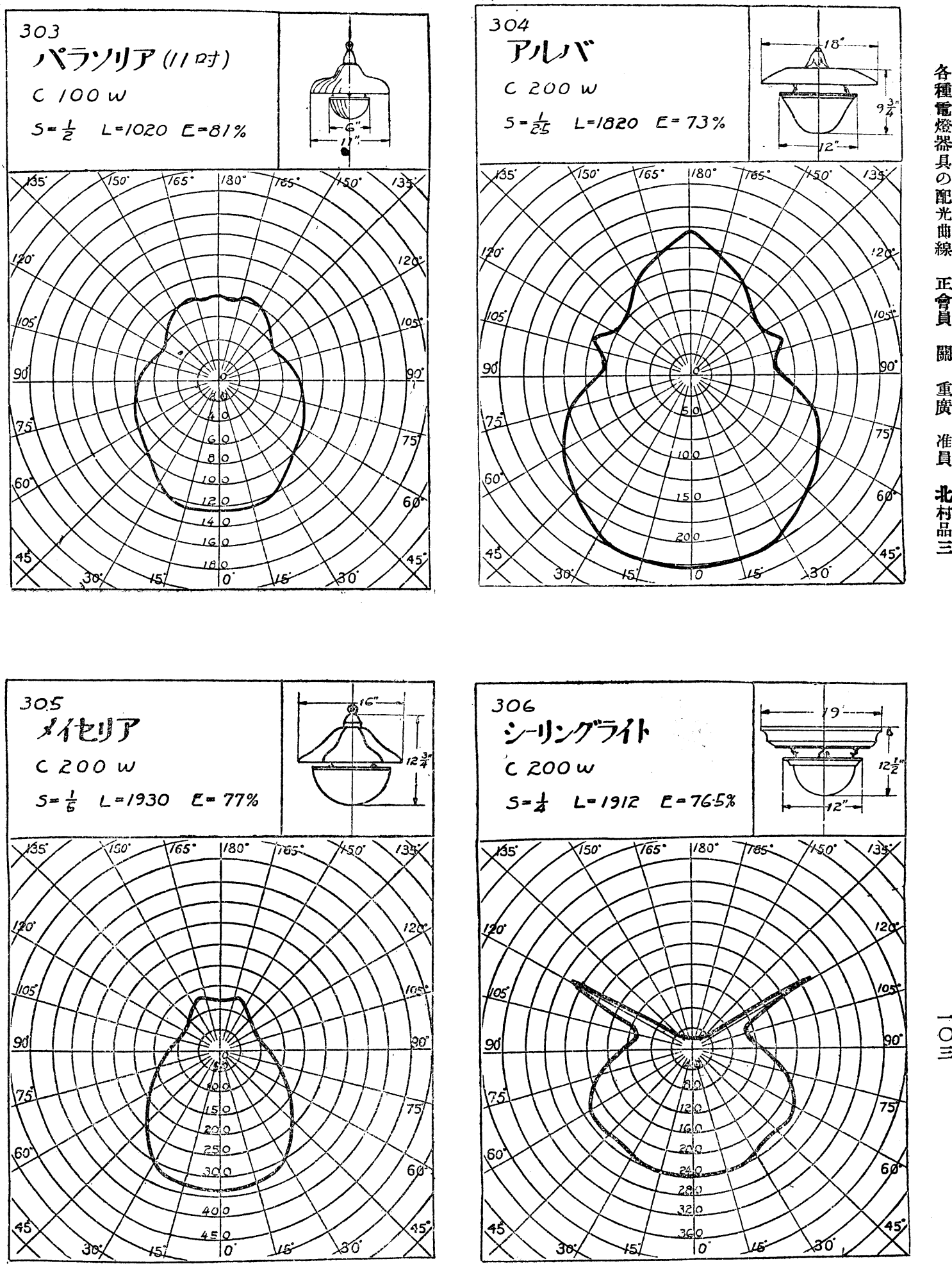

$\overrightarrow{\mathrm{O}}$ 

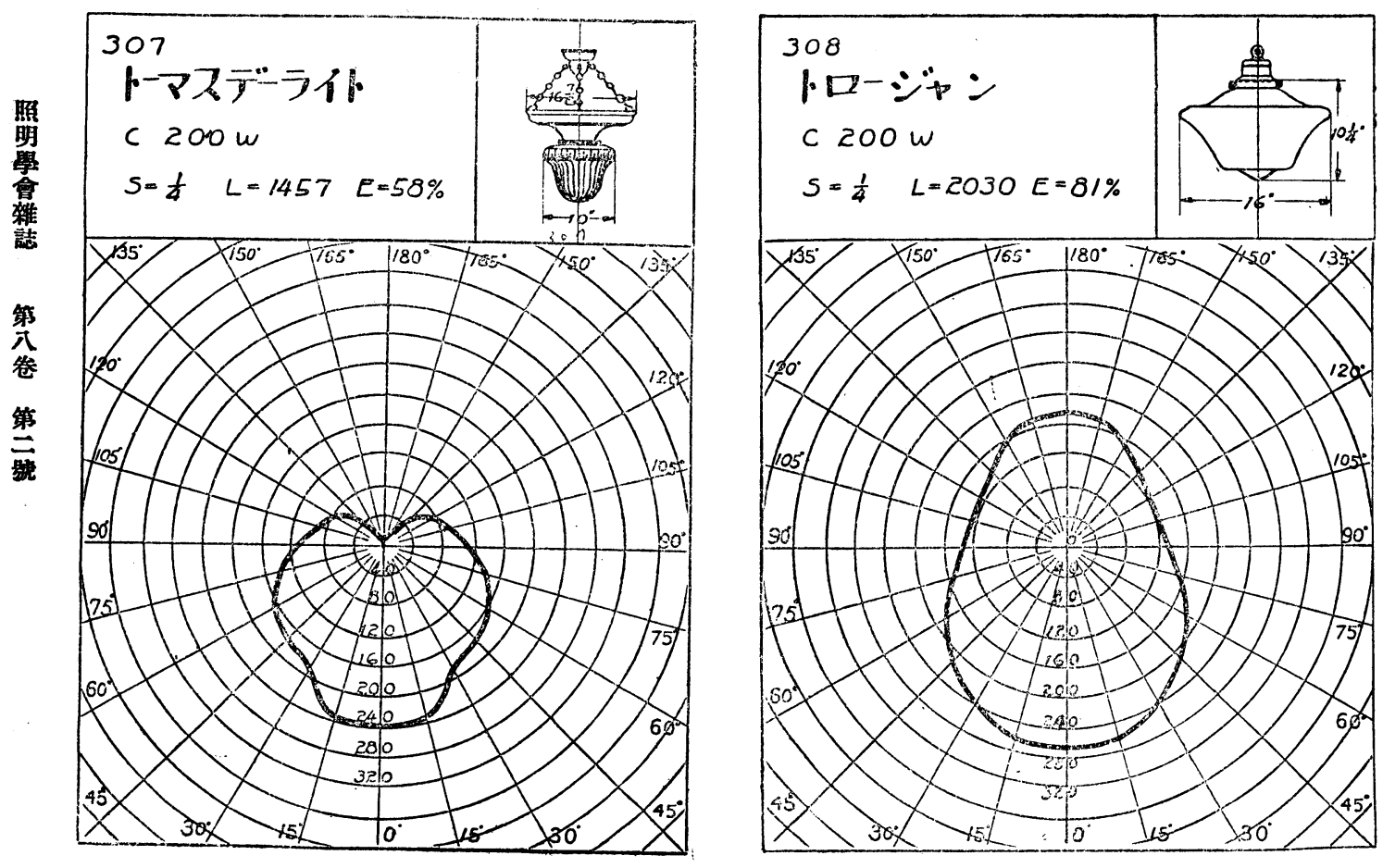

普 通 反 射 笠
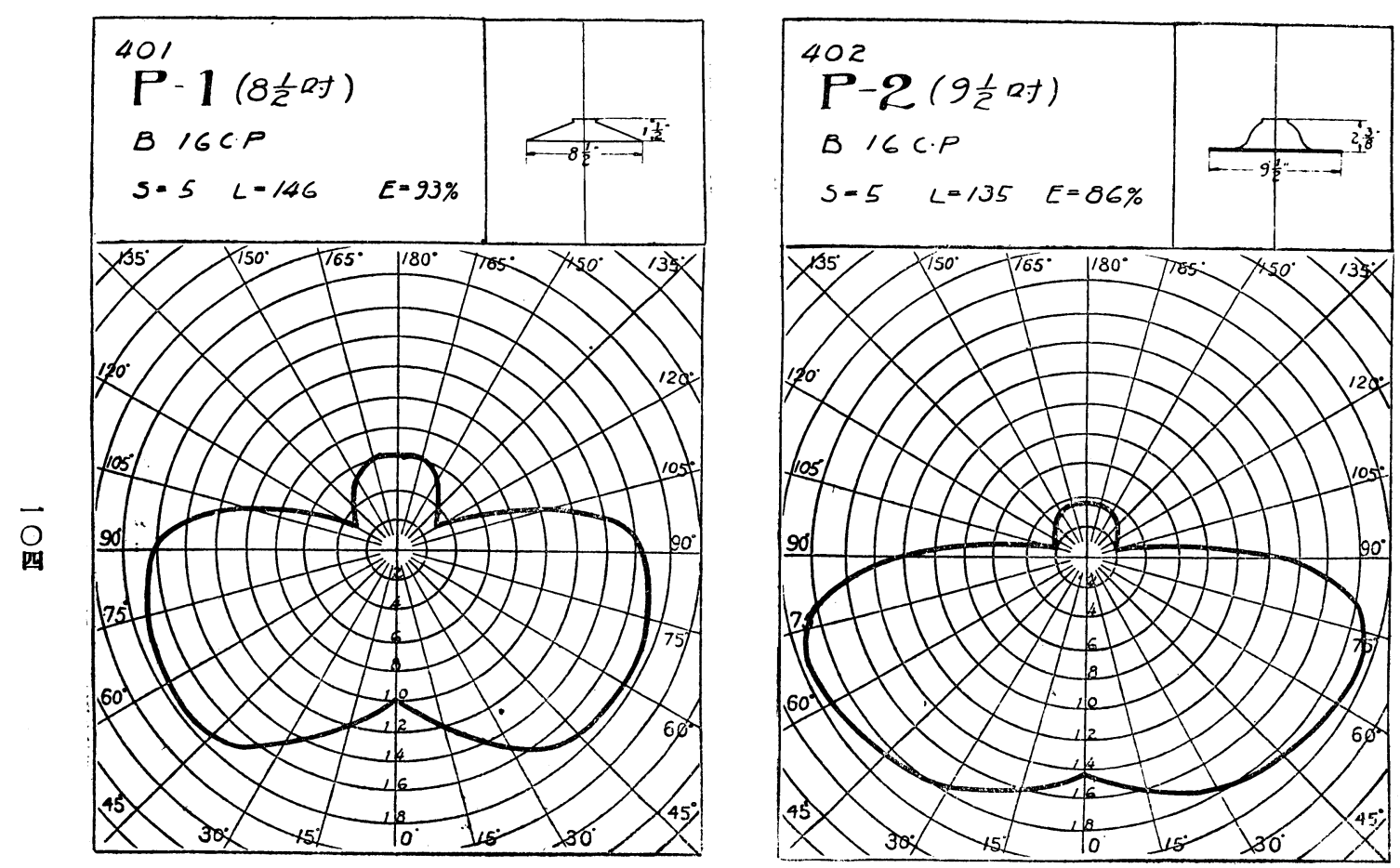

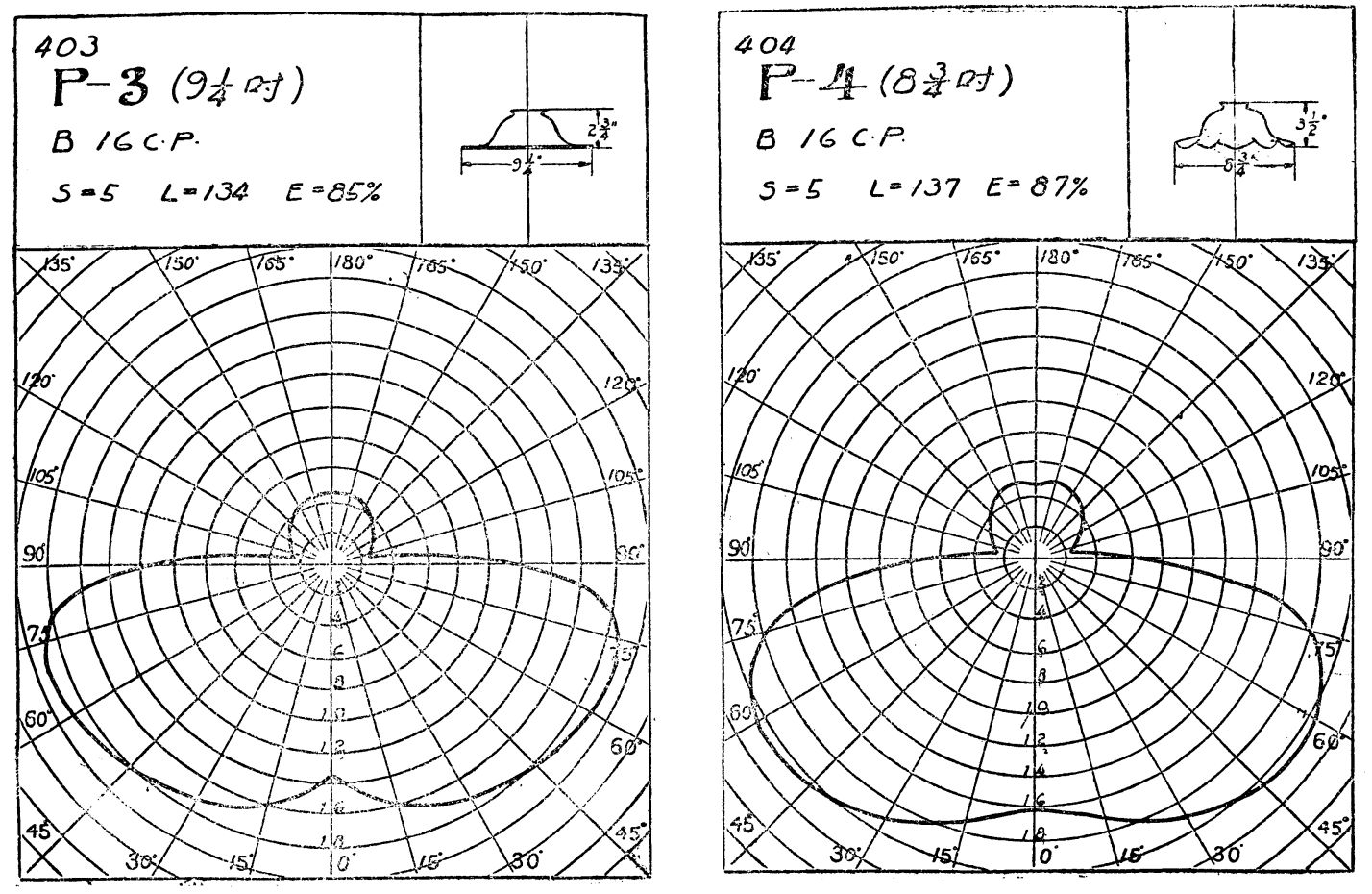

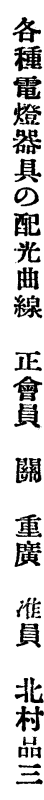
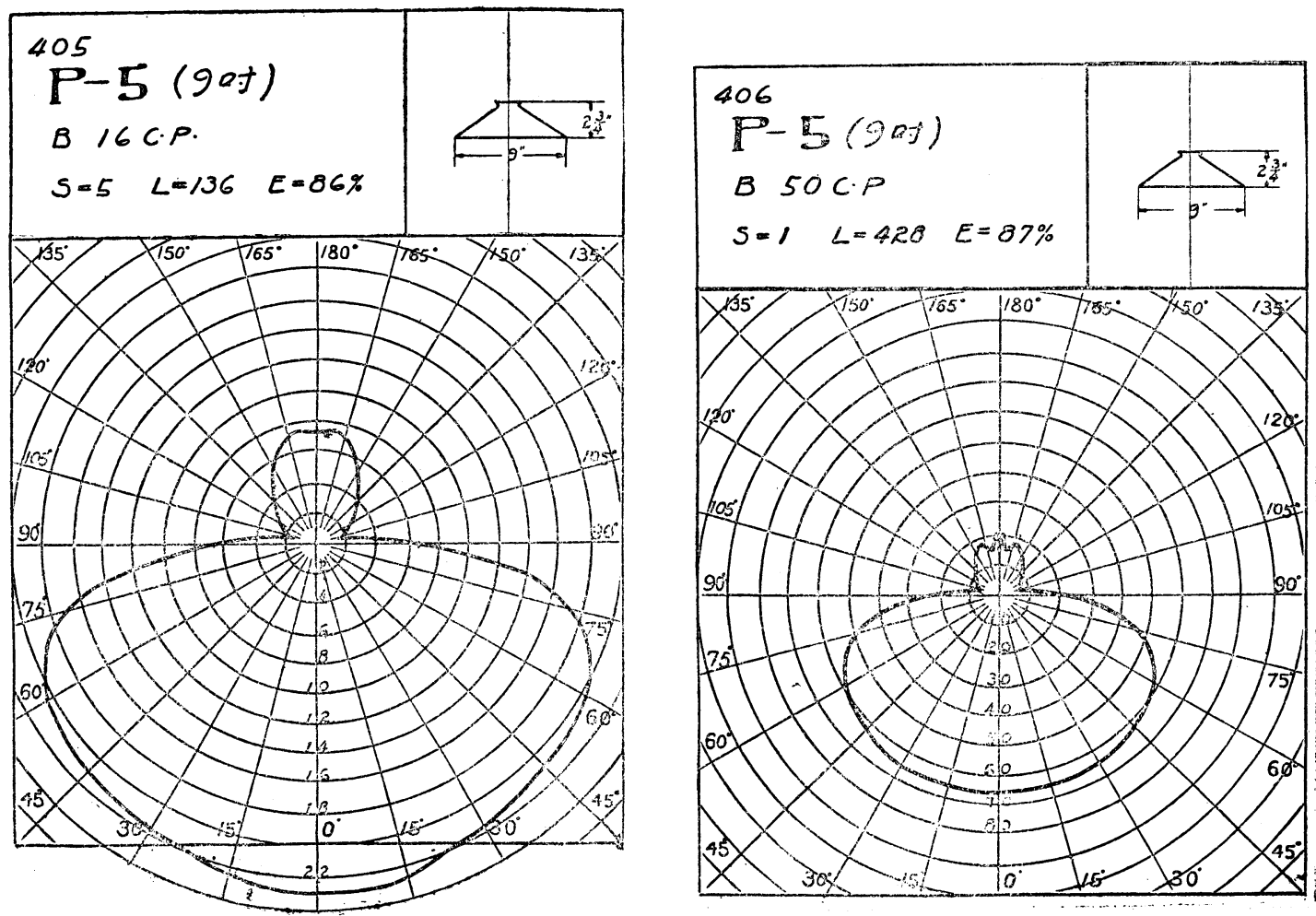

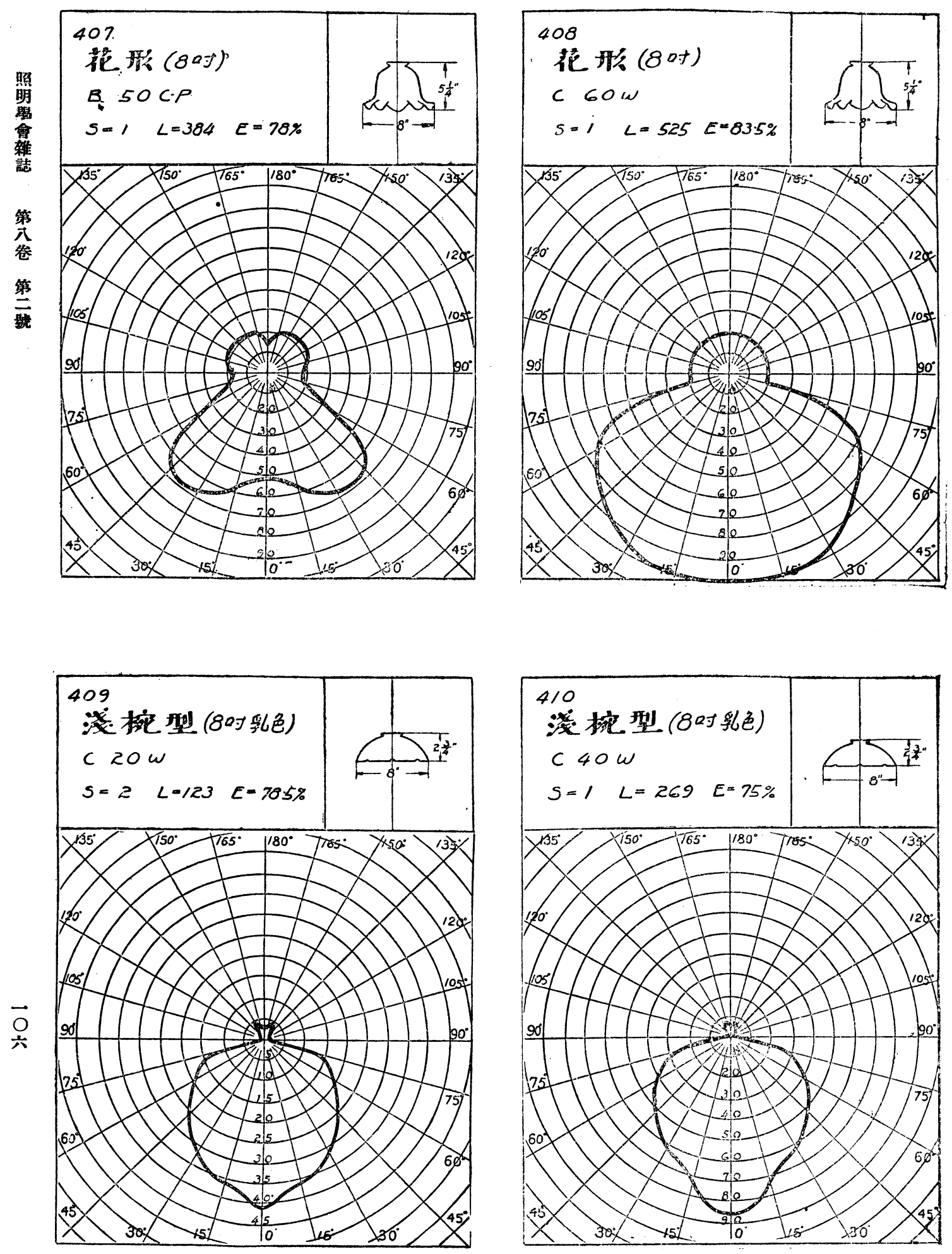

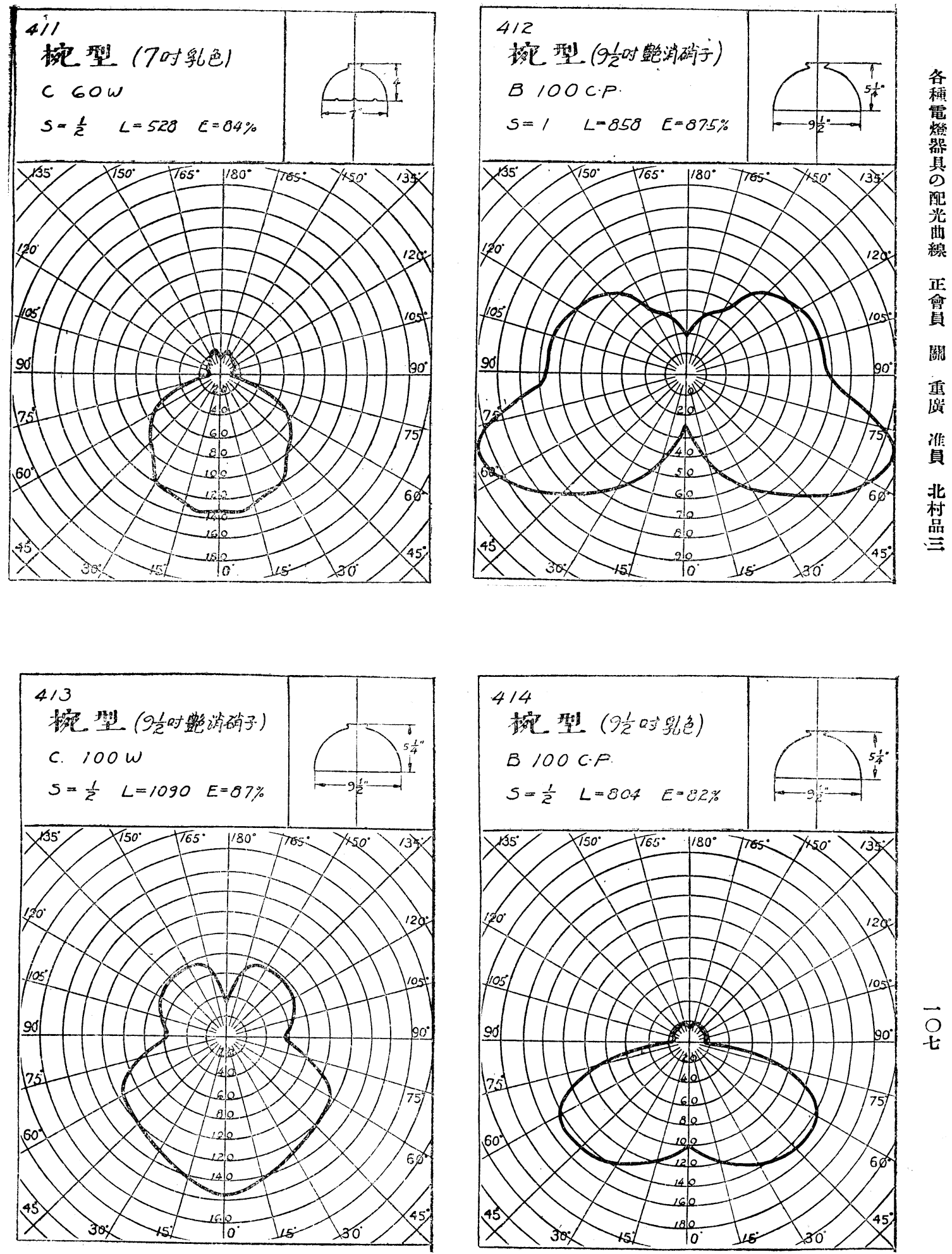

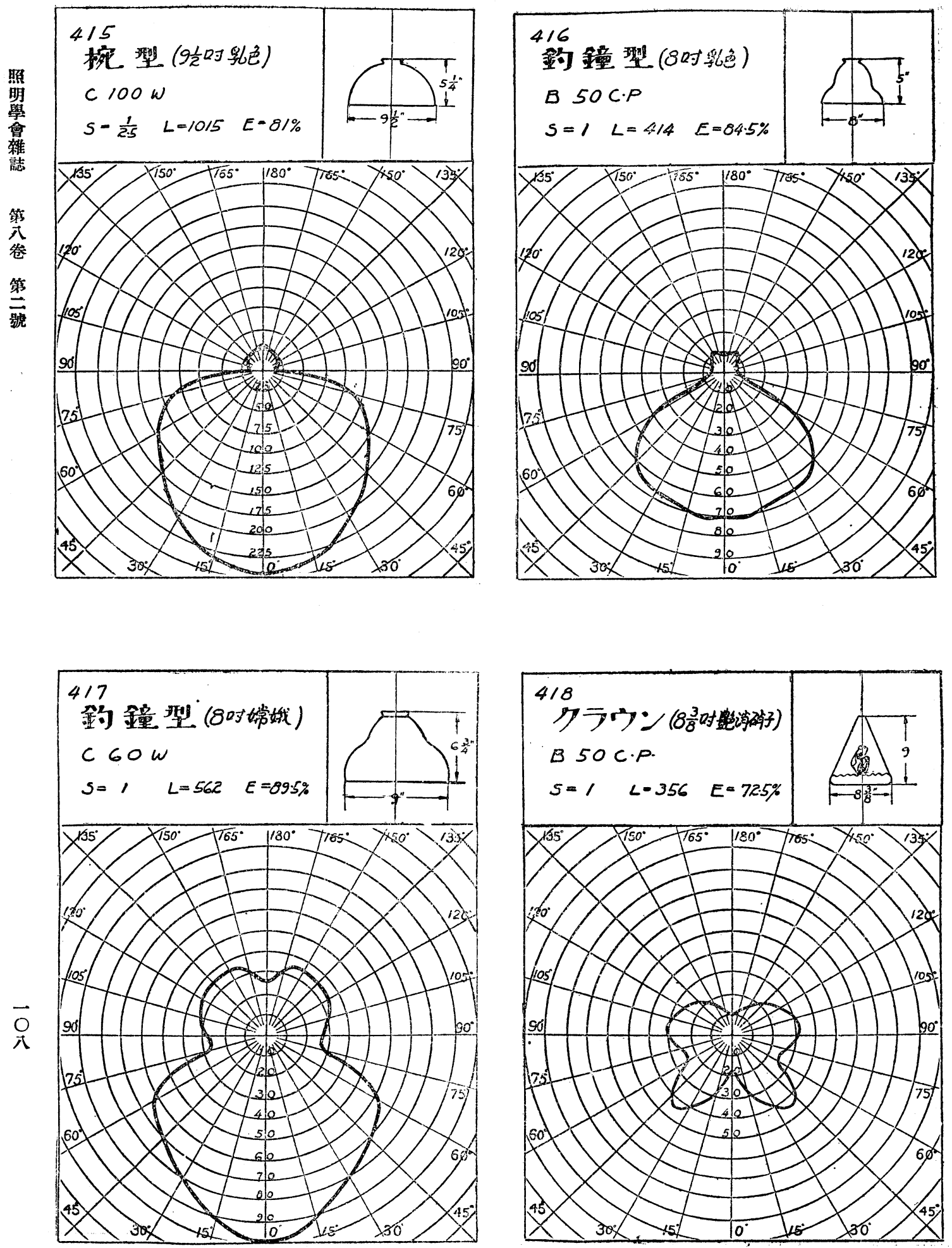

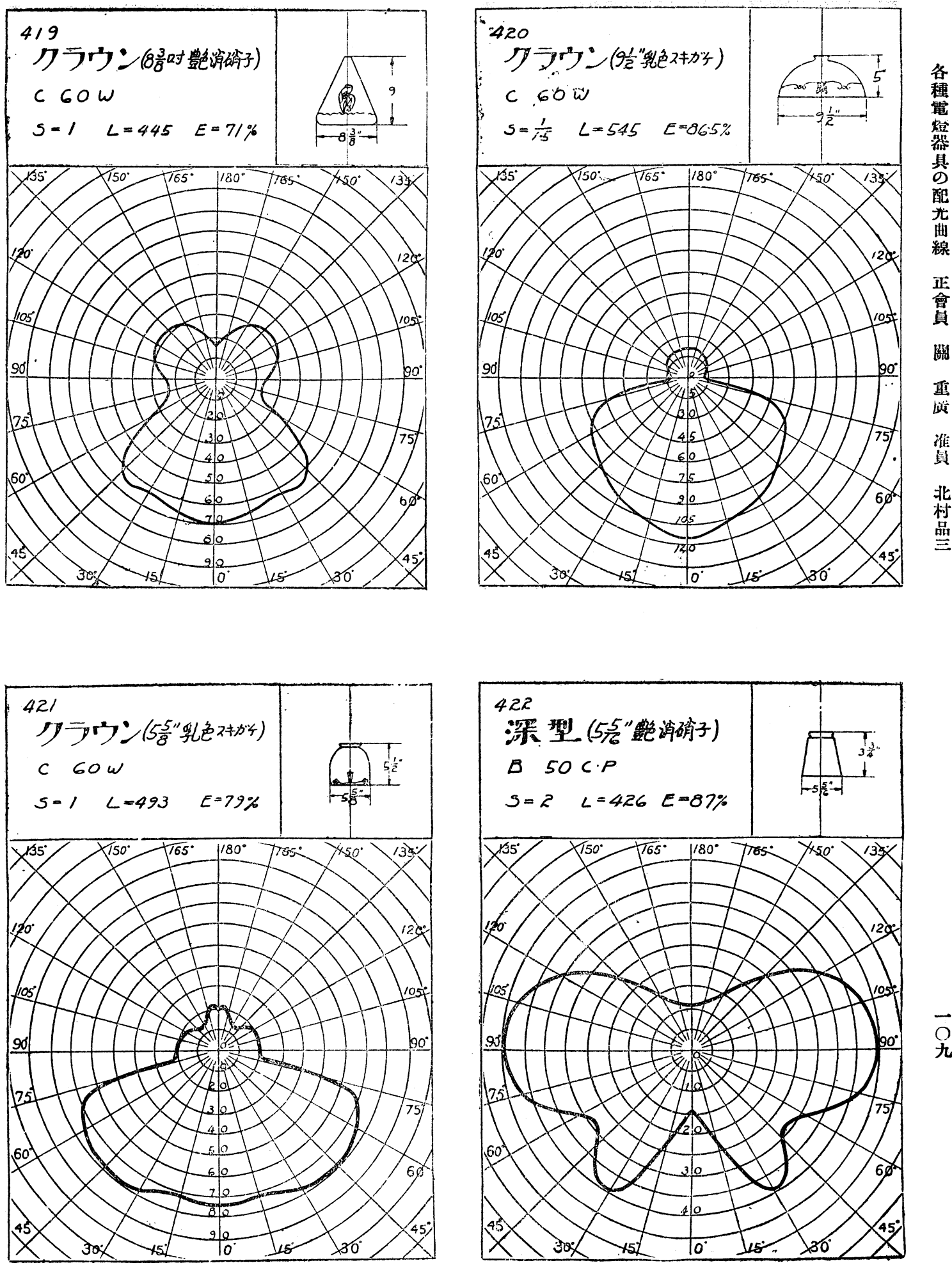

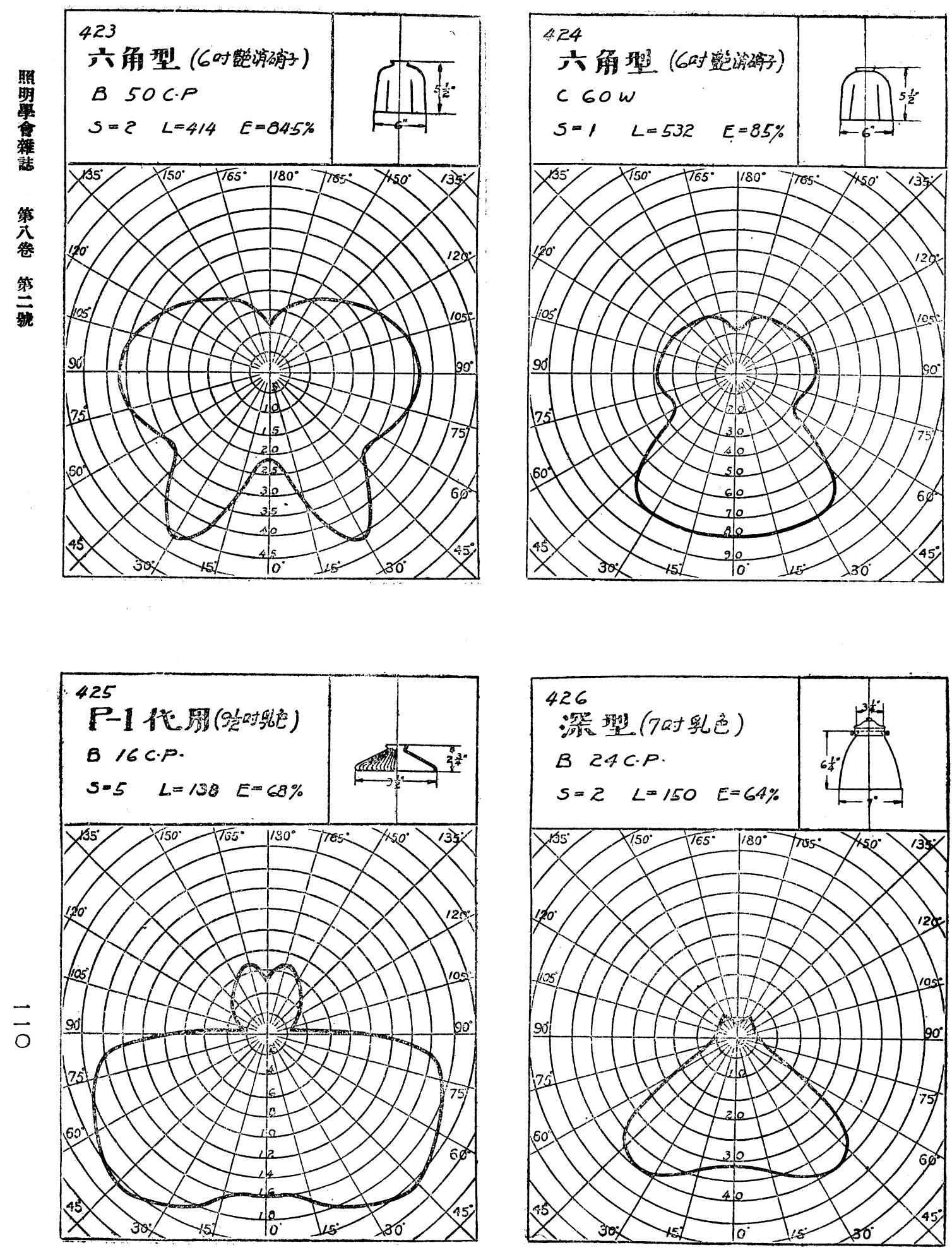

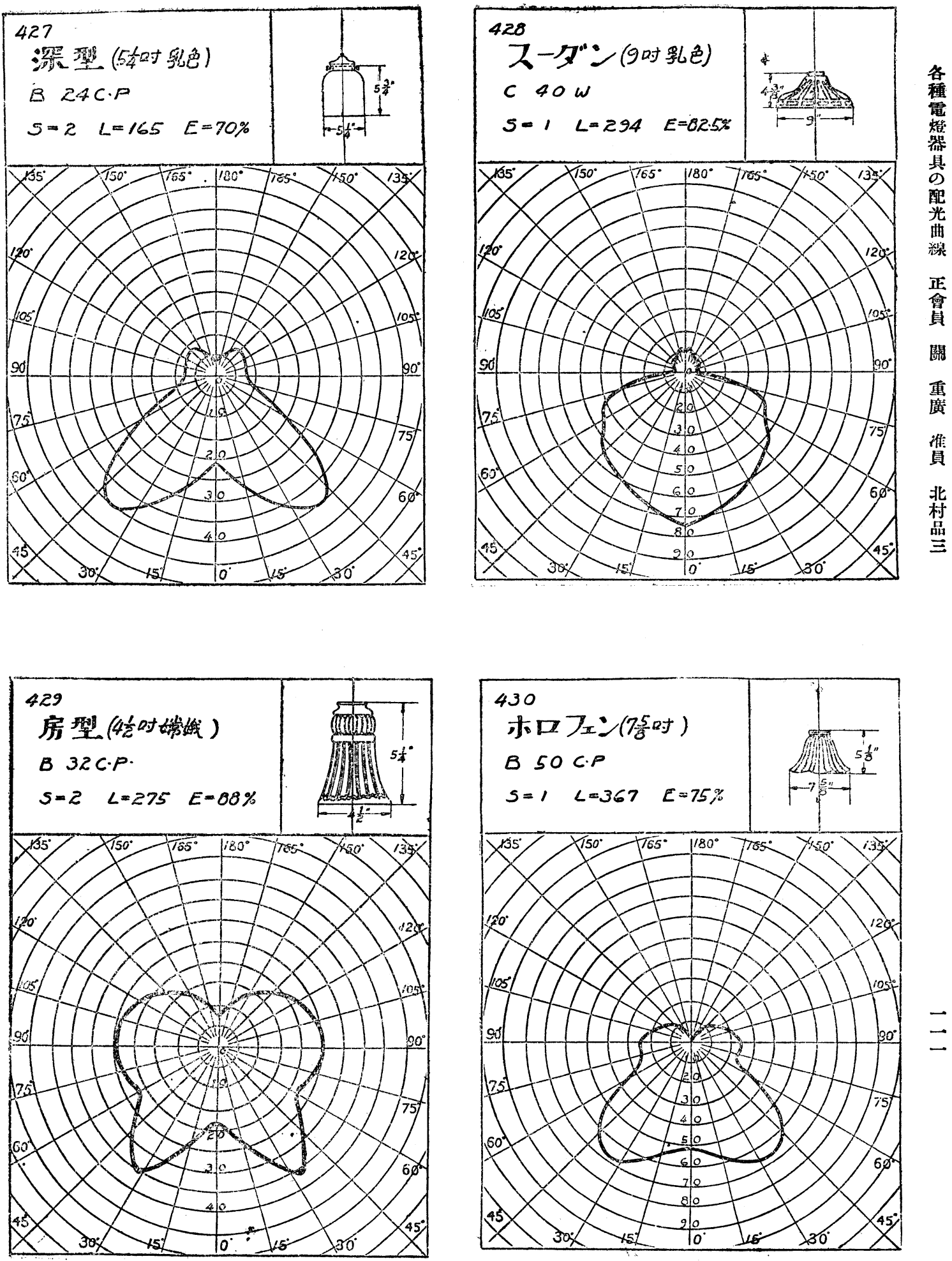

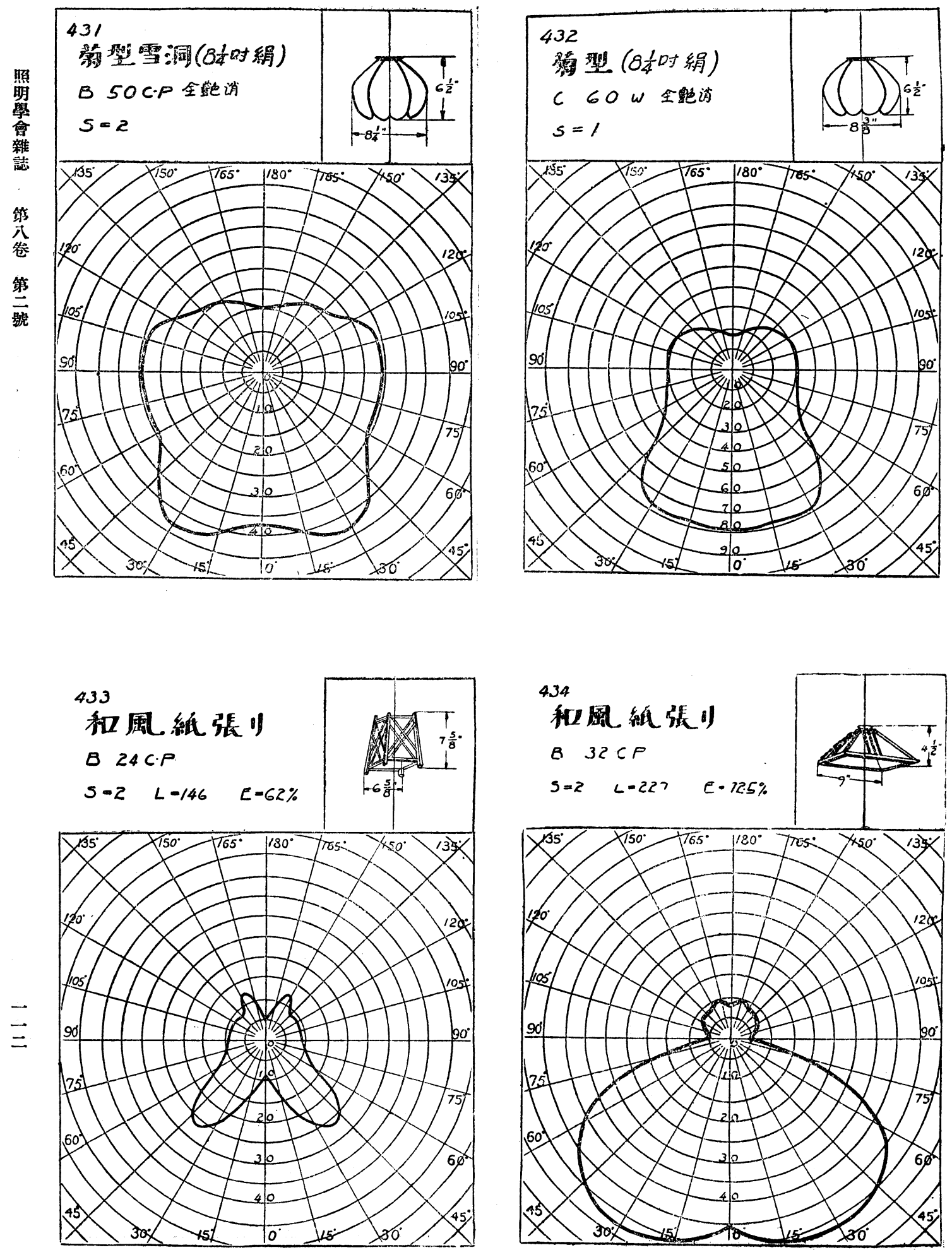

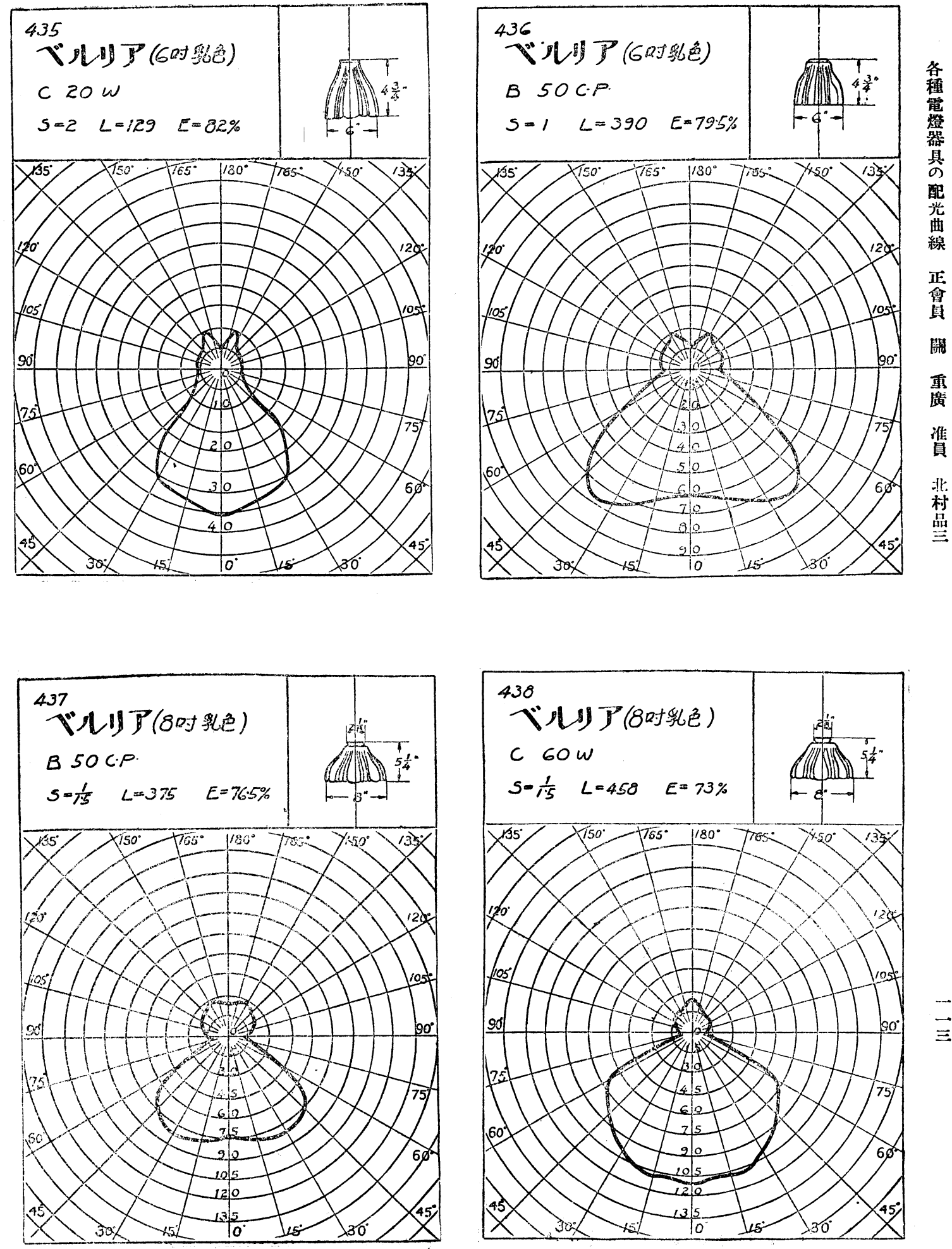

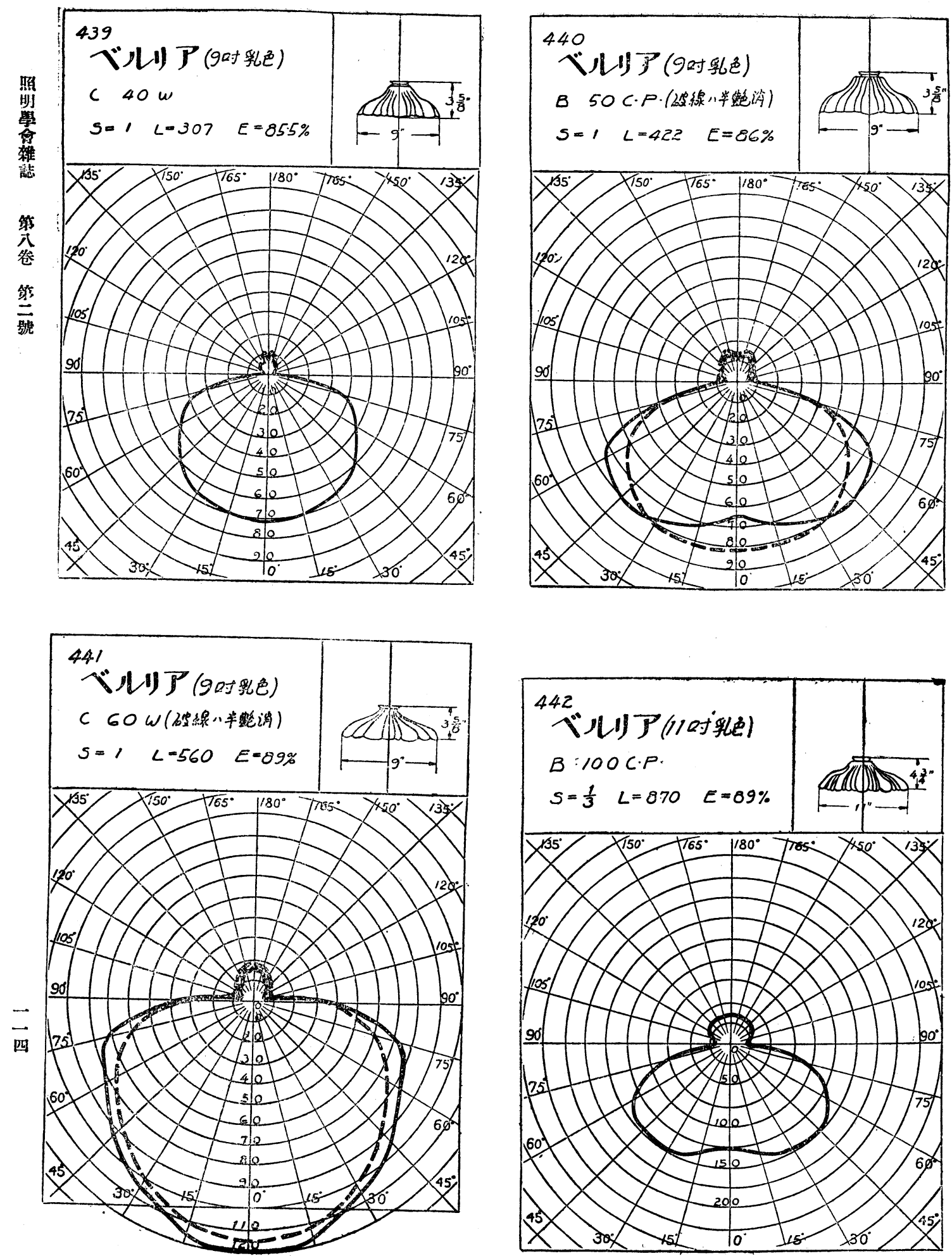

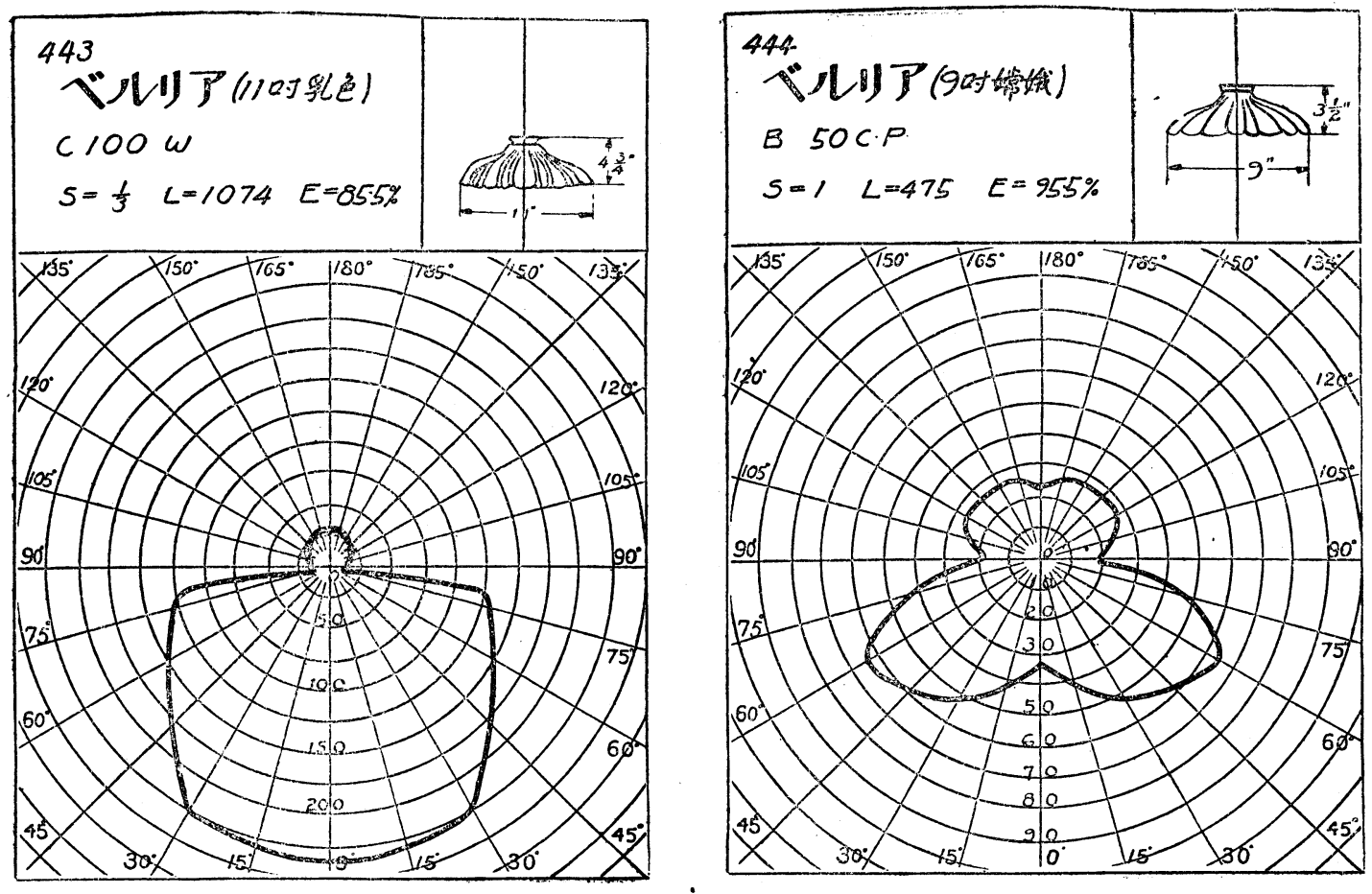

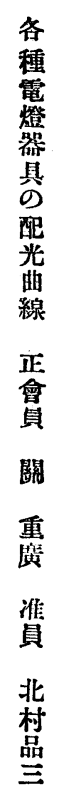

鏡面 反 射笠
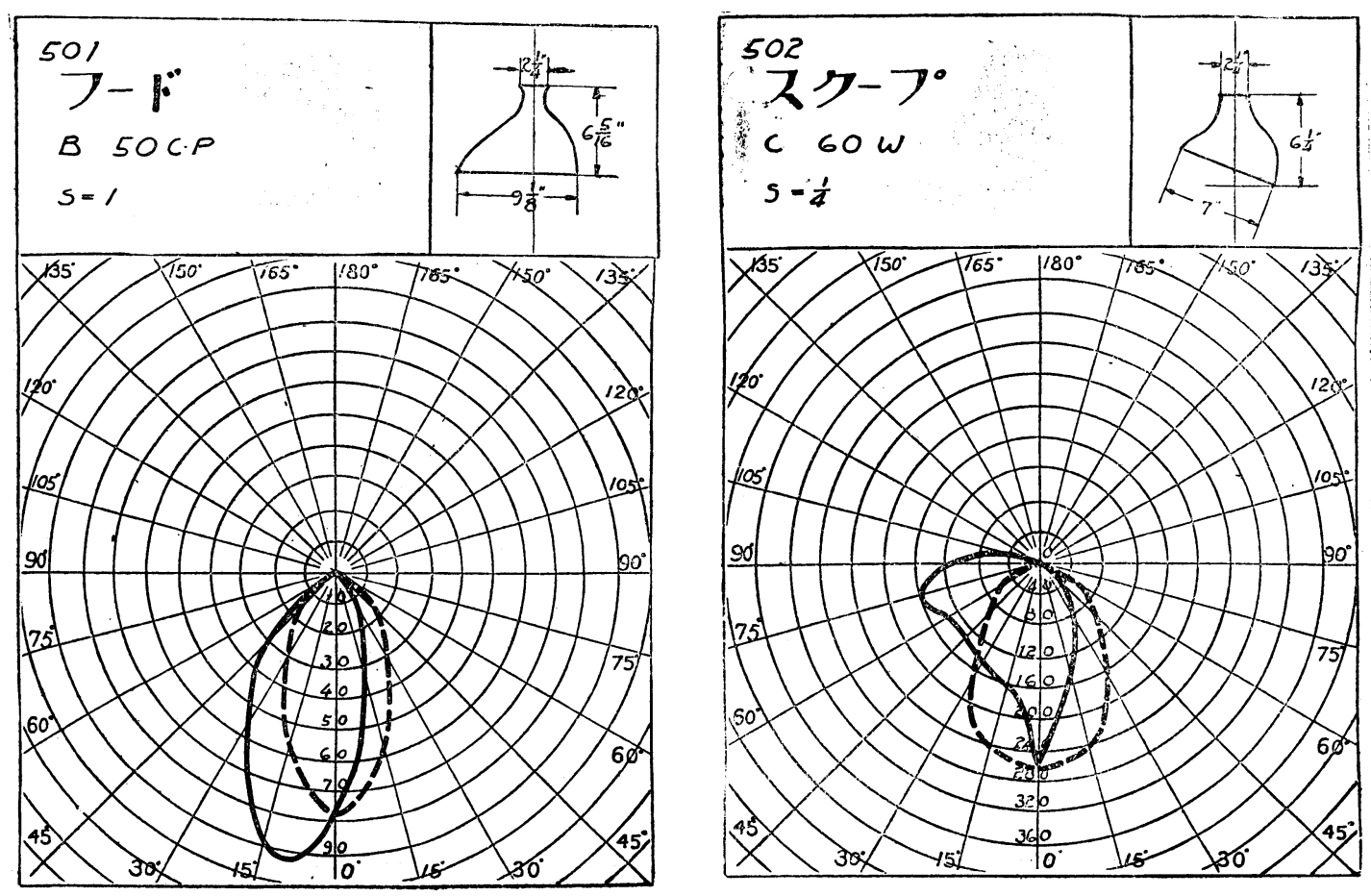

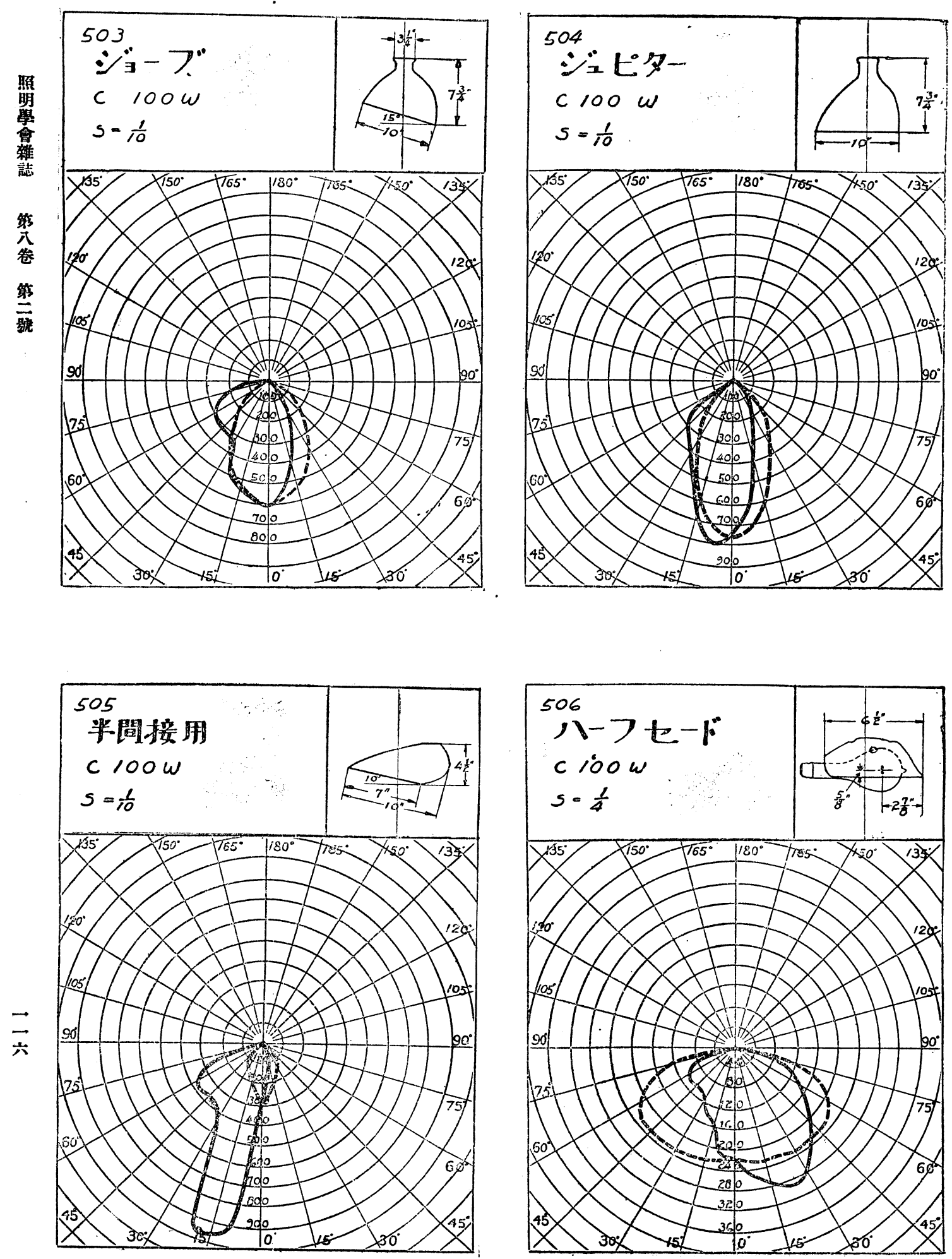
金 屬 反 射 笠
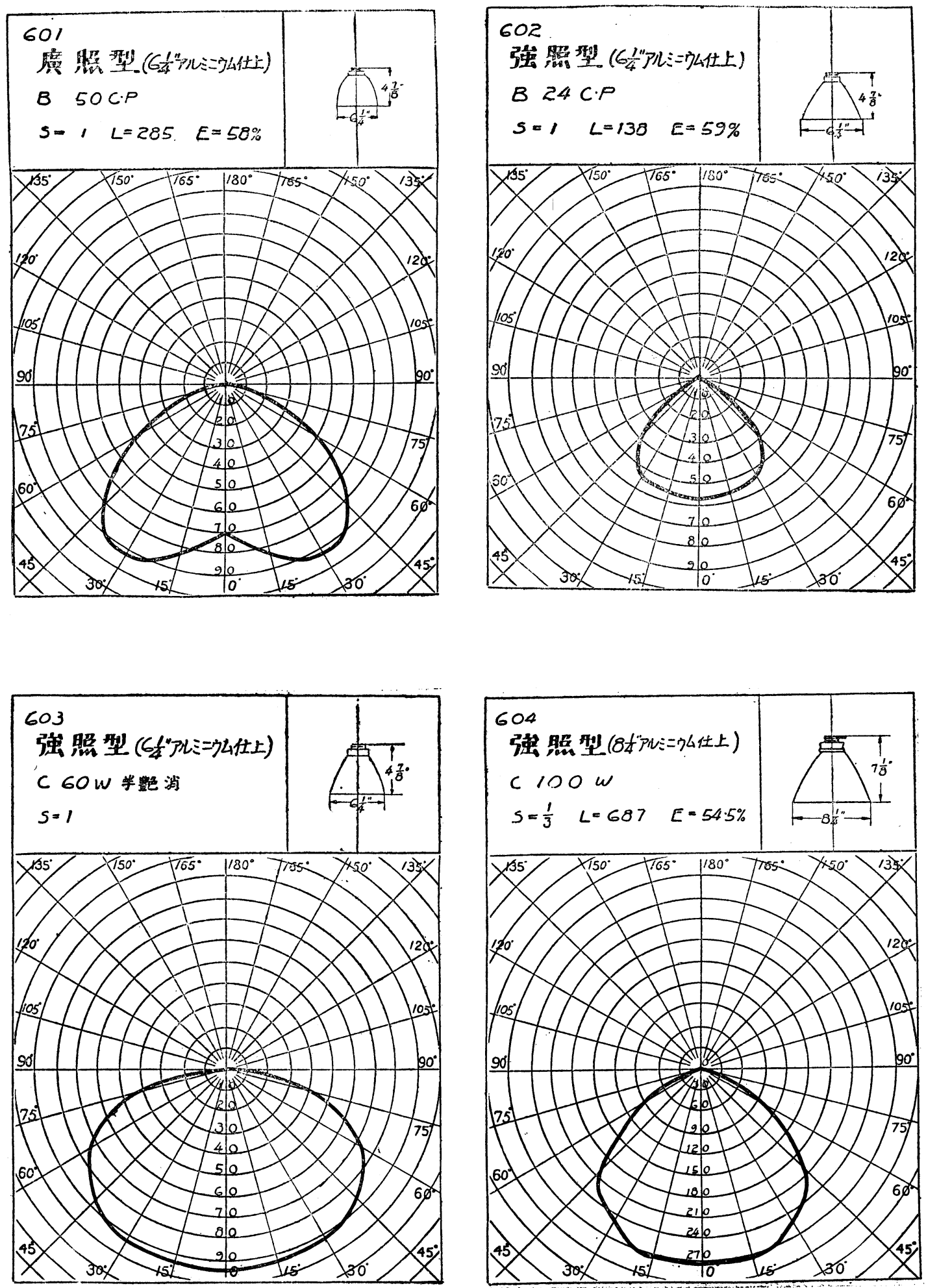

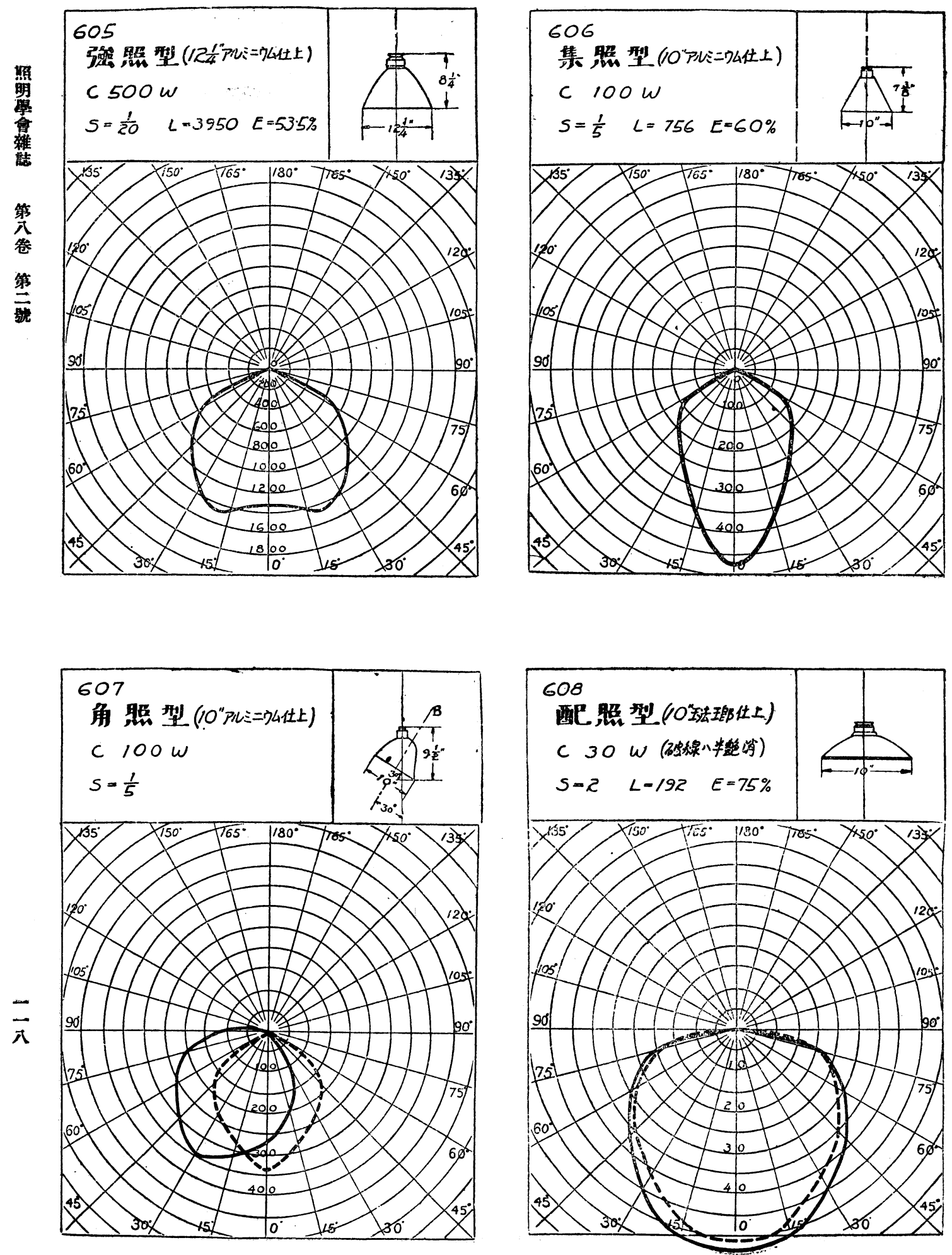

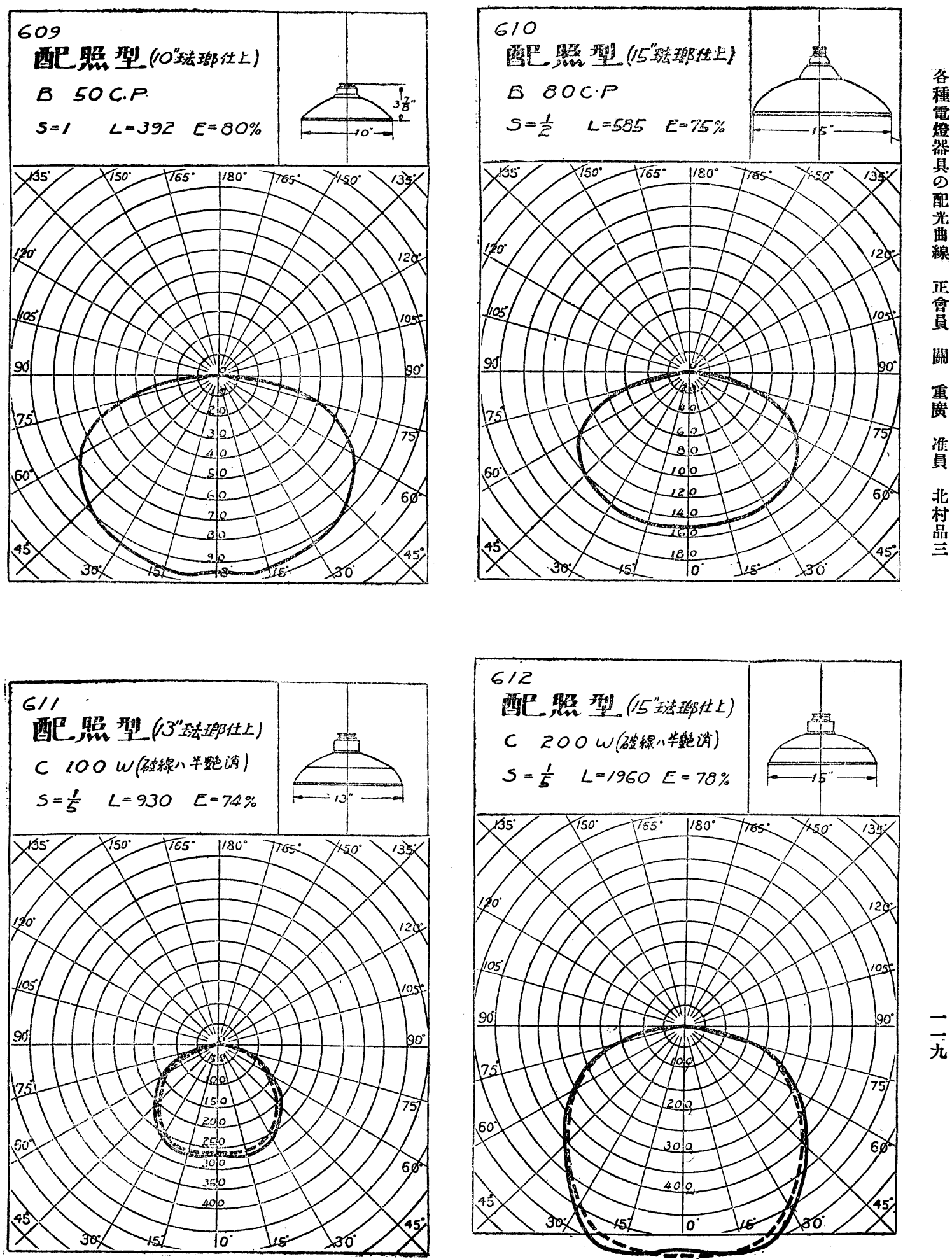


\section{屋外用グローブ}
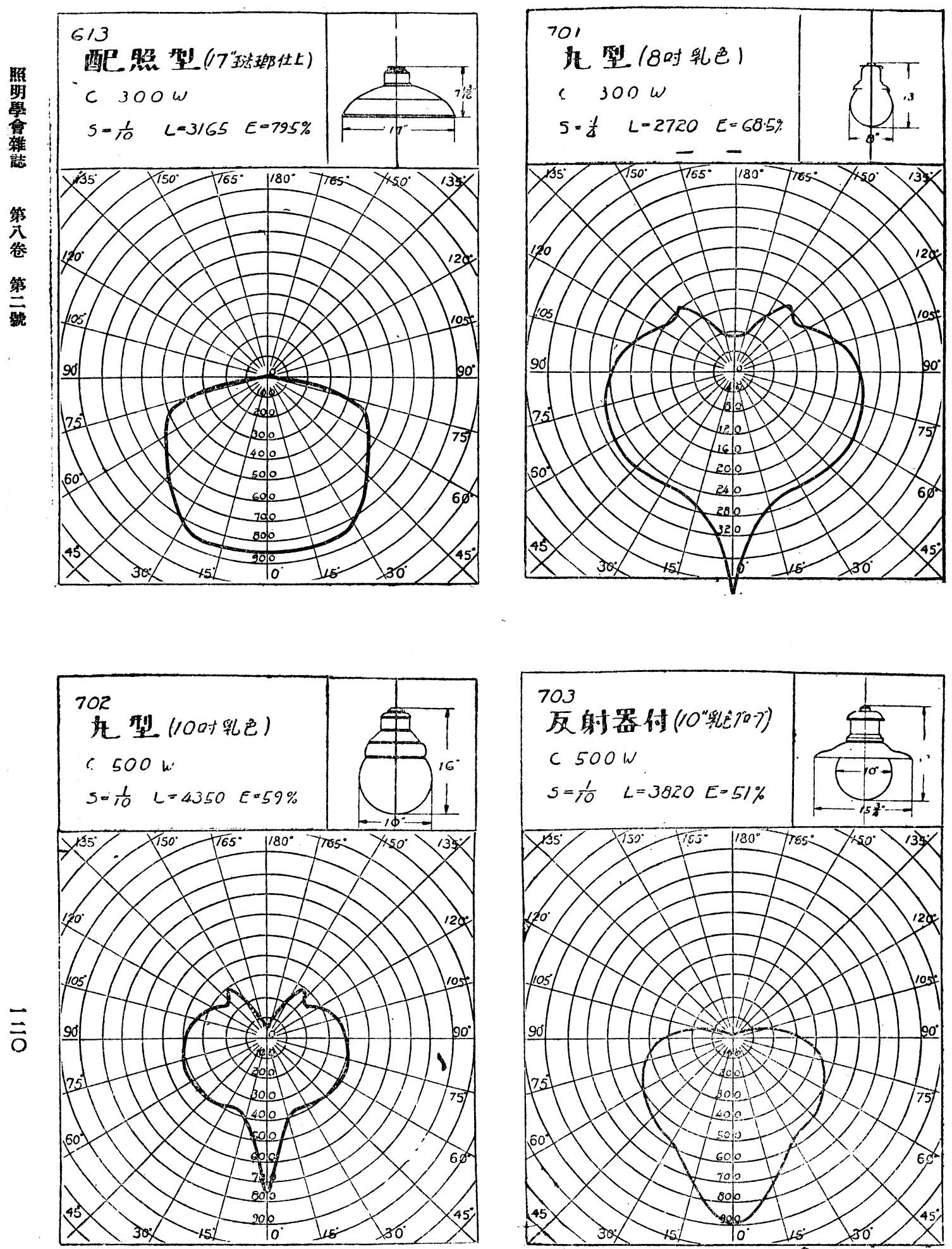

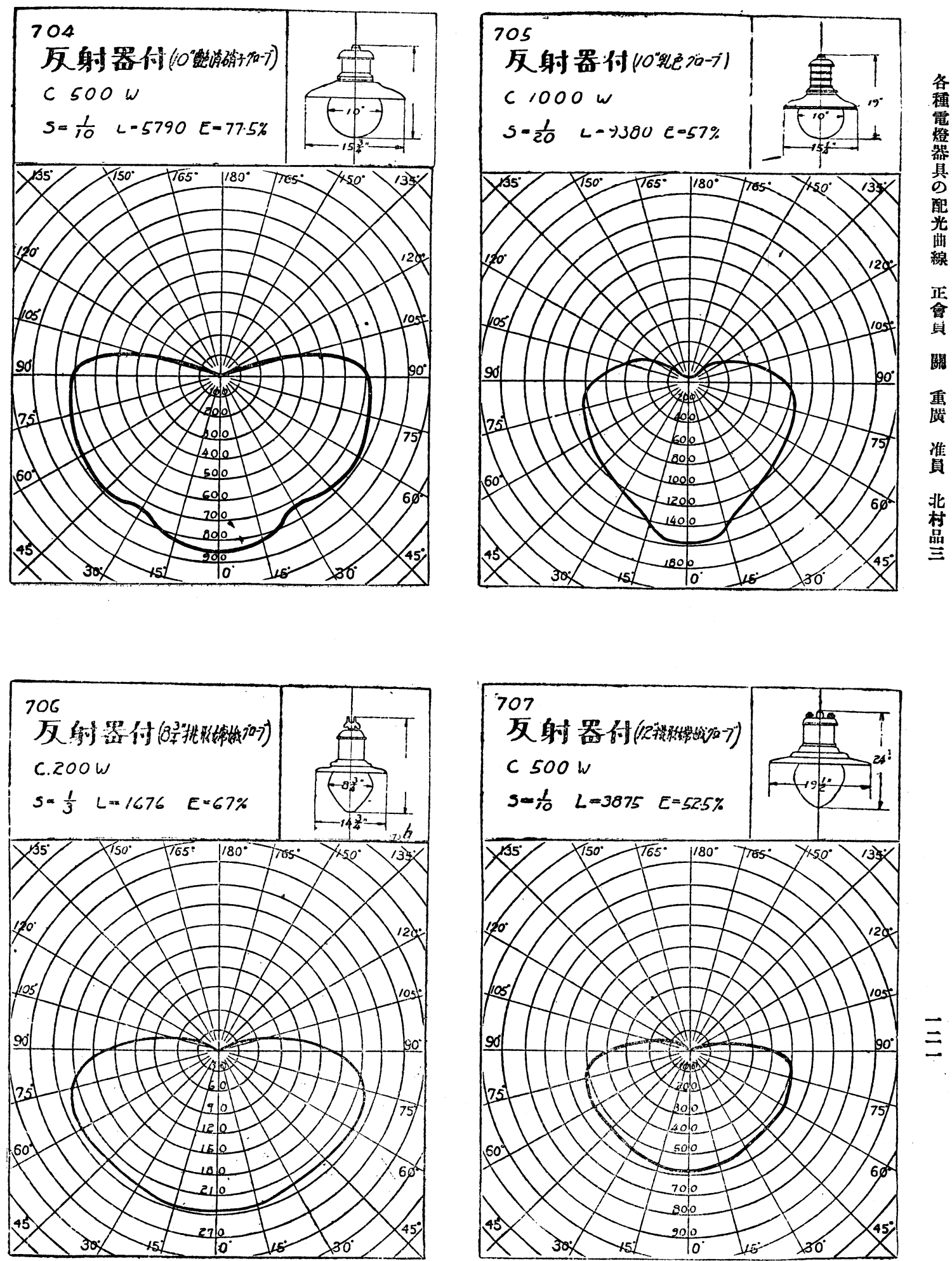
特 殊 器 具
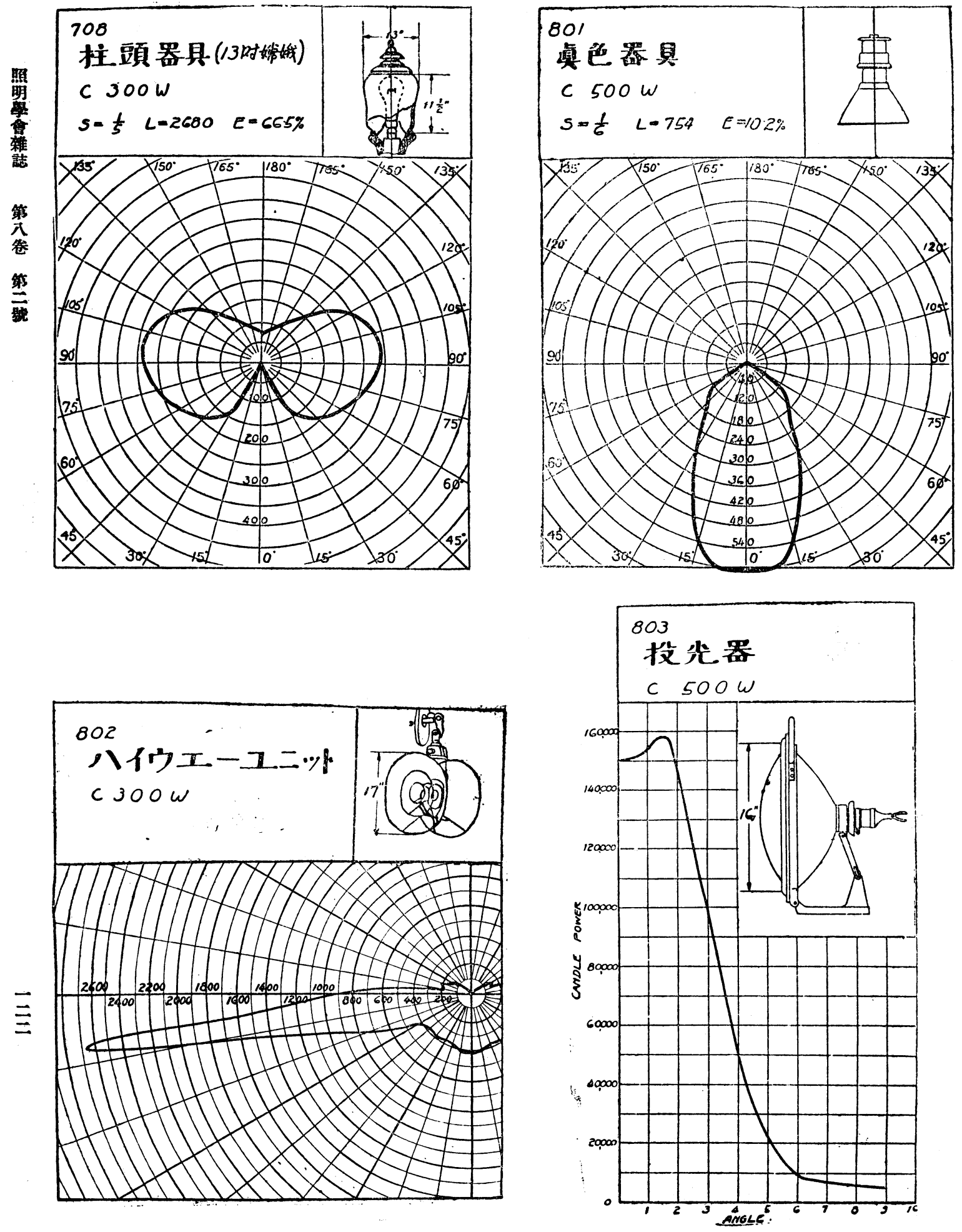


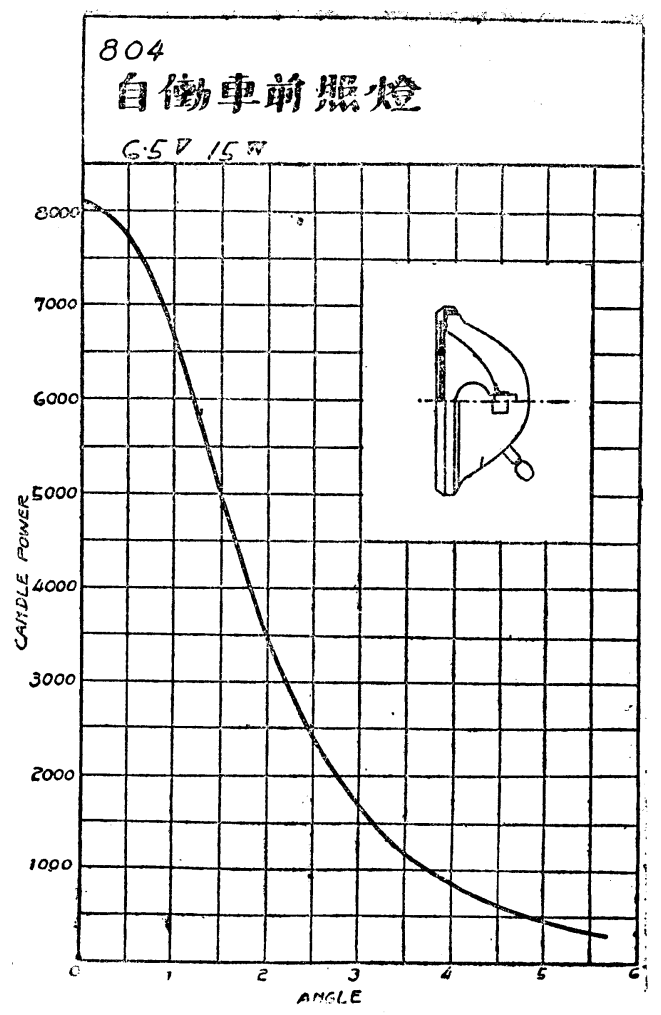

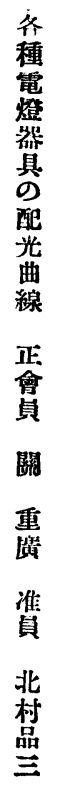

三 
間接照明器具 (101)

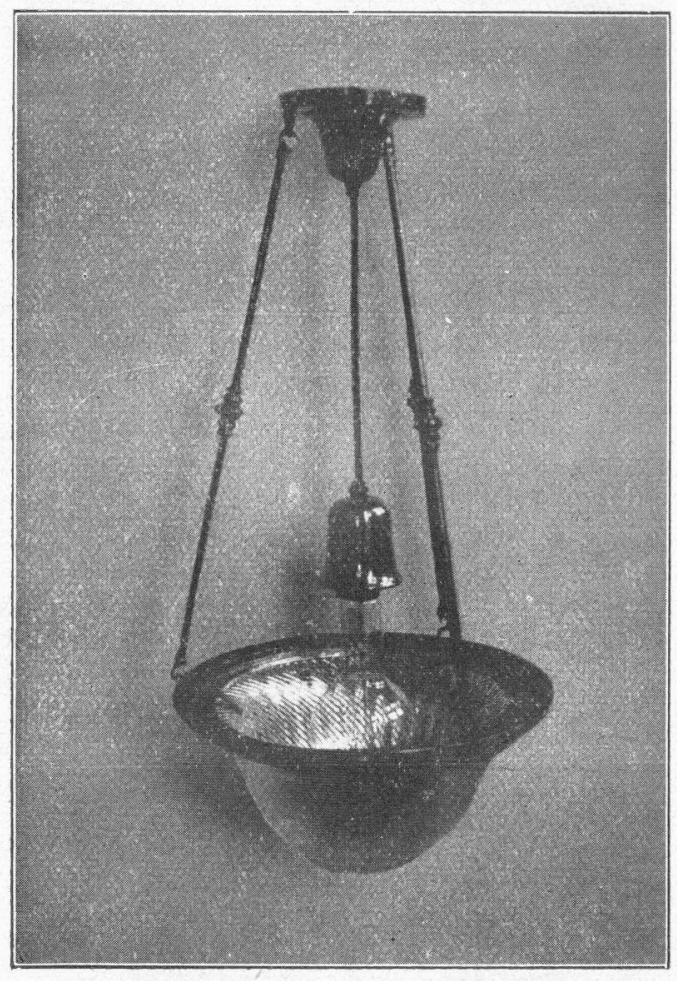

(202)

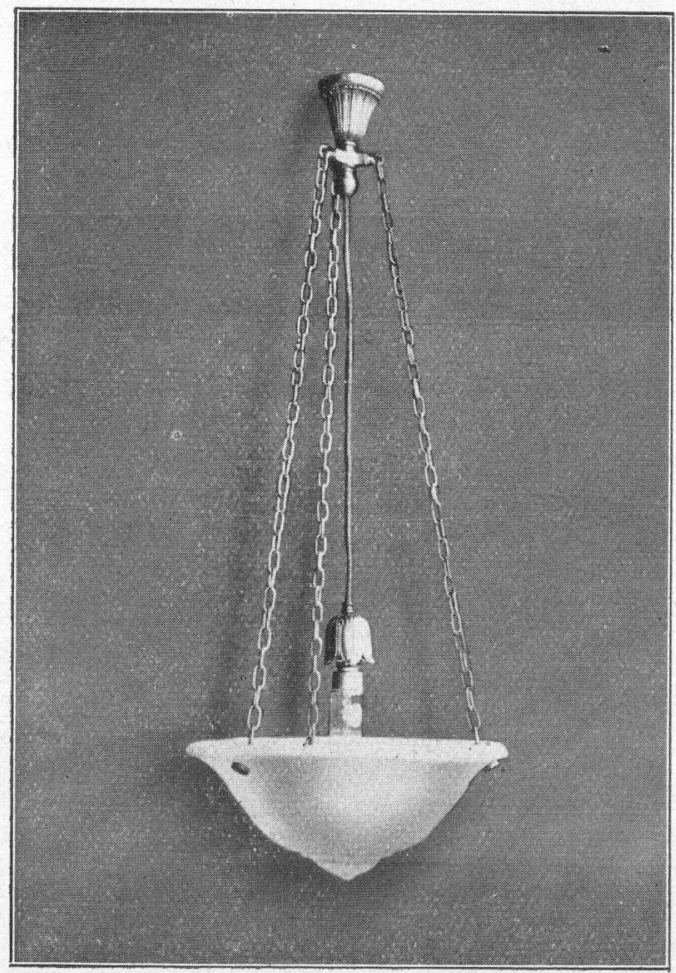

牛閒接照明器具 (201)

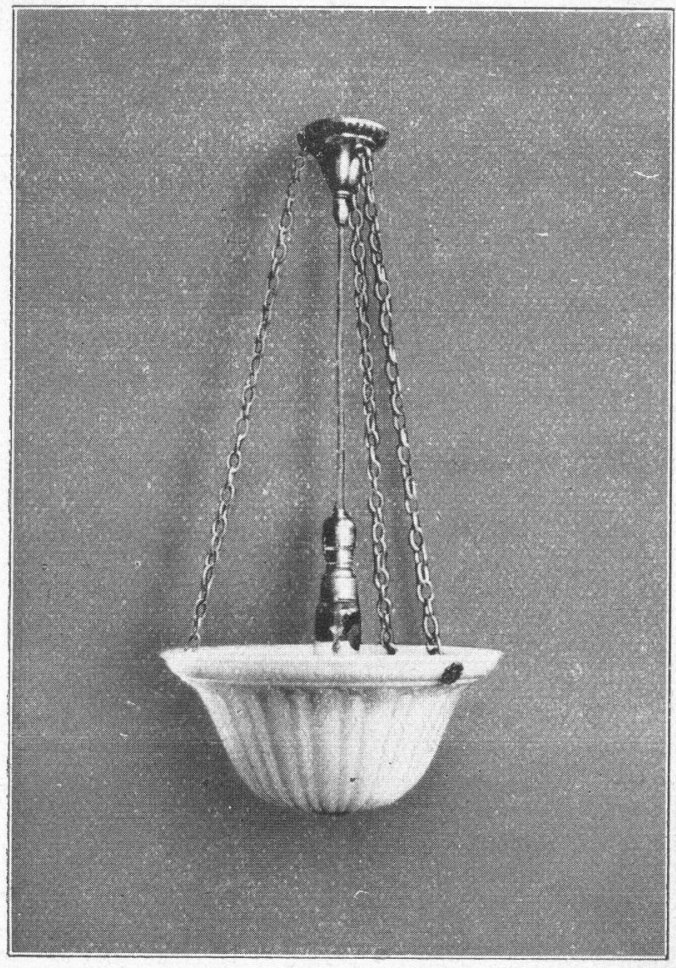

(203)

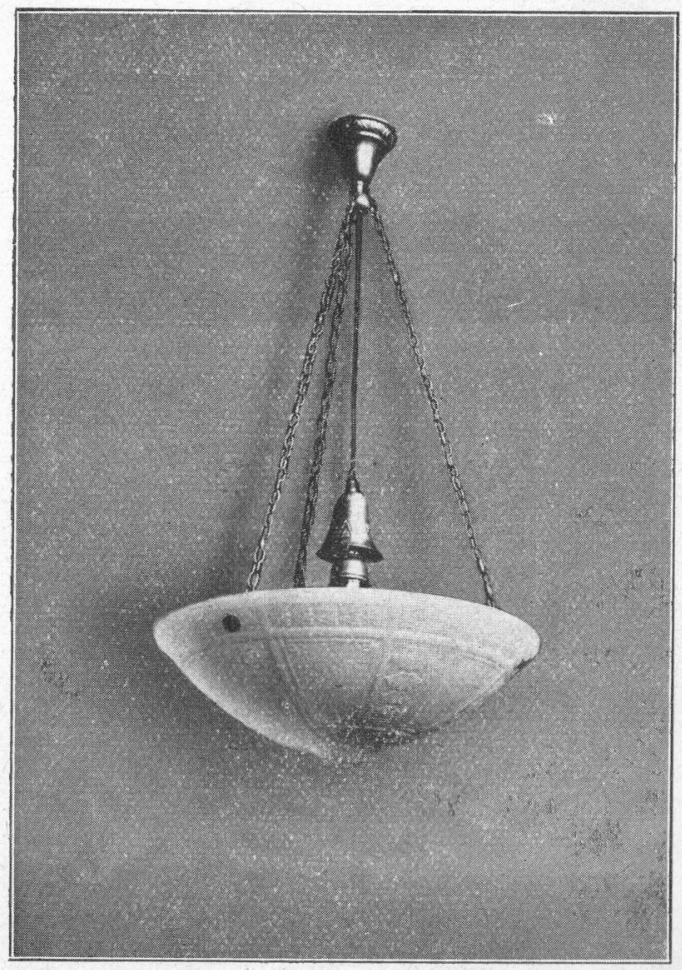


(204)

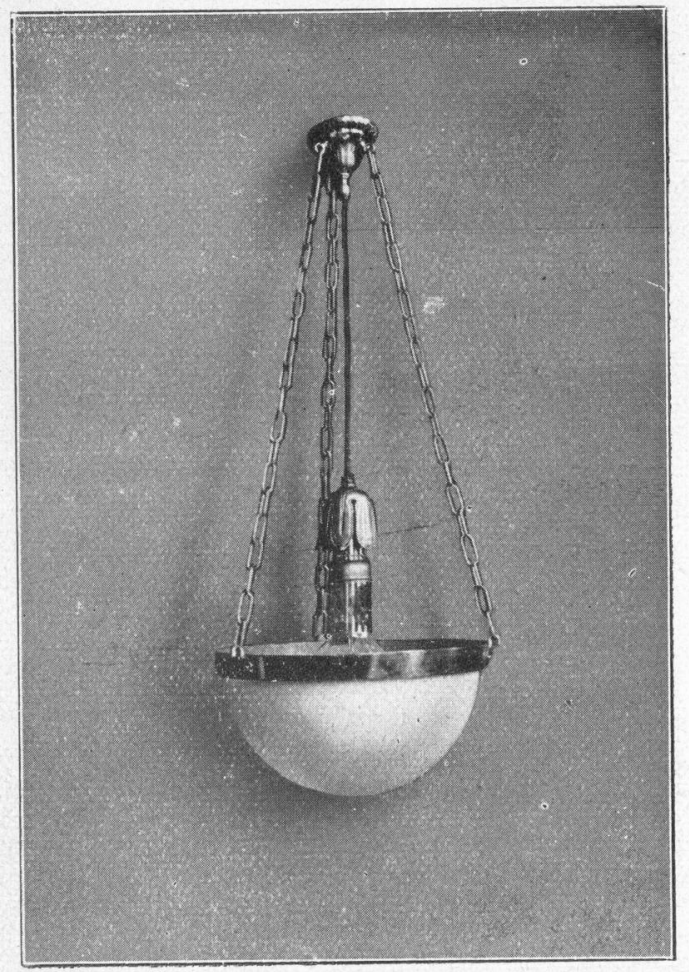

(206)

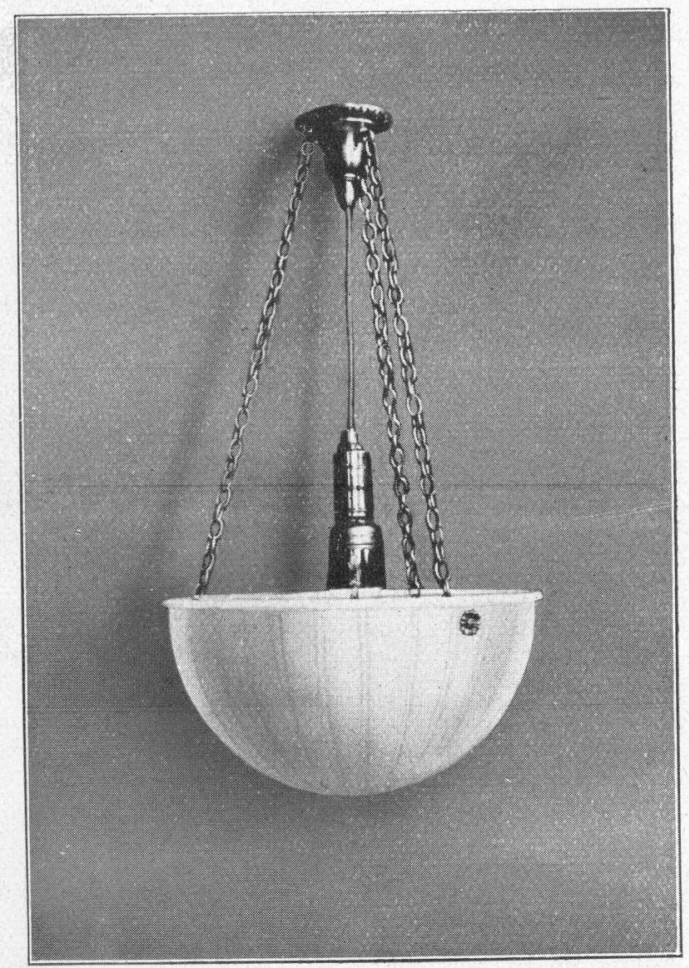

(205)

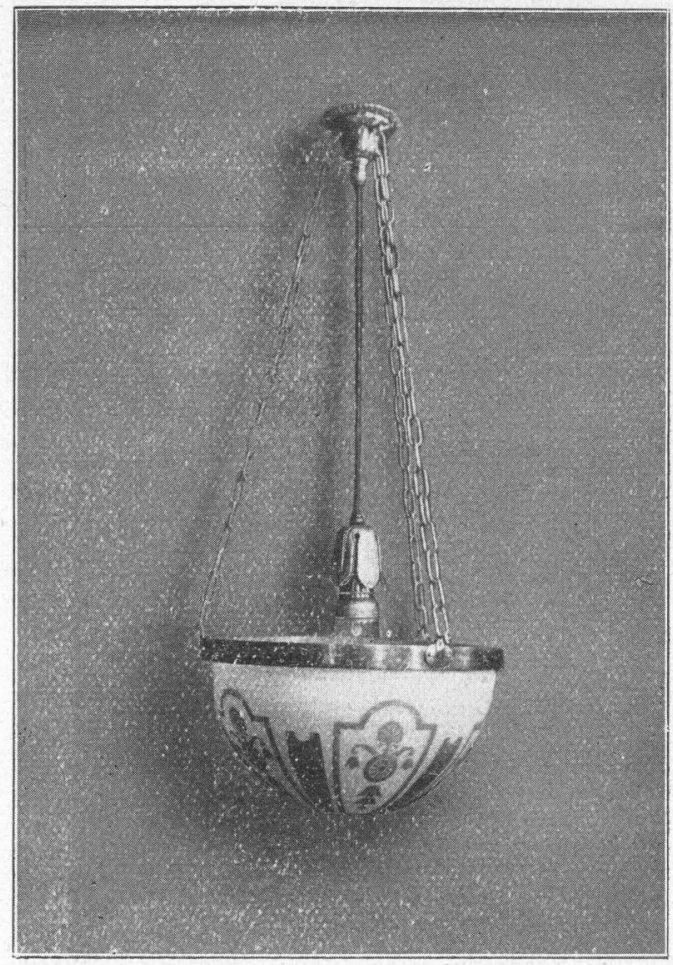

(207)

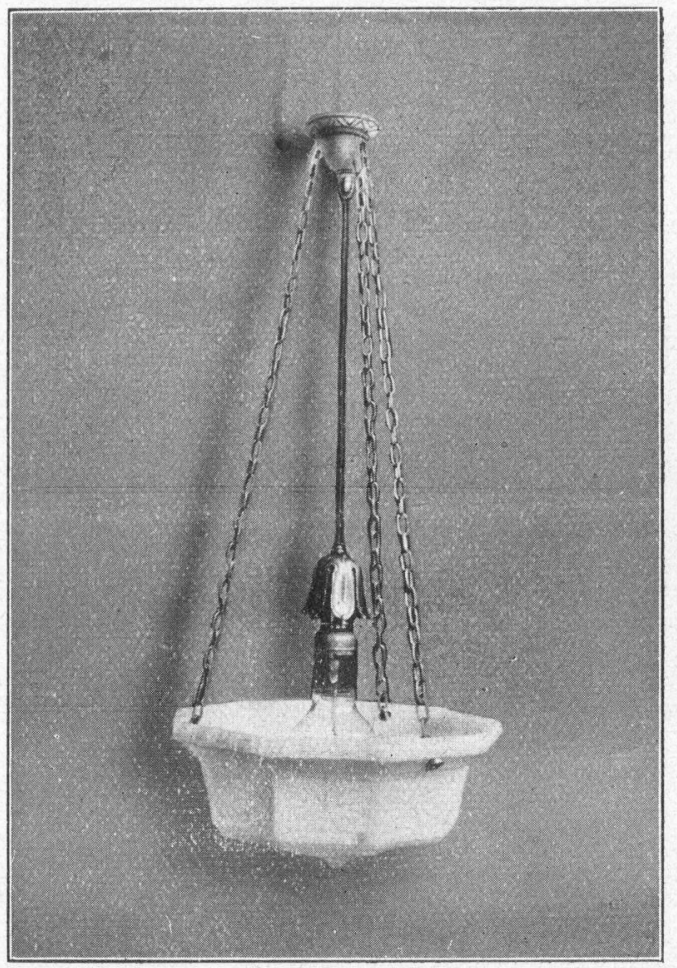


(208)

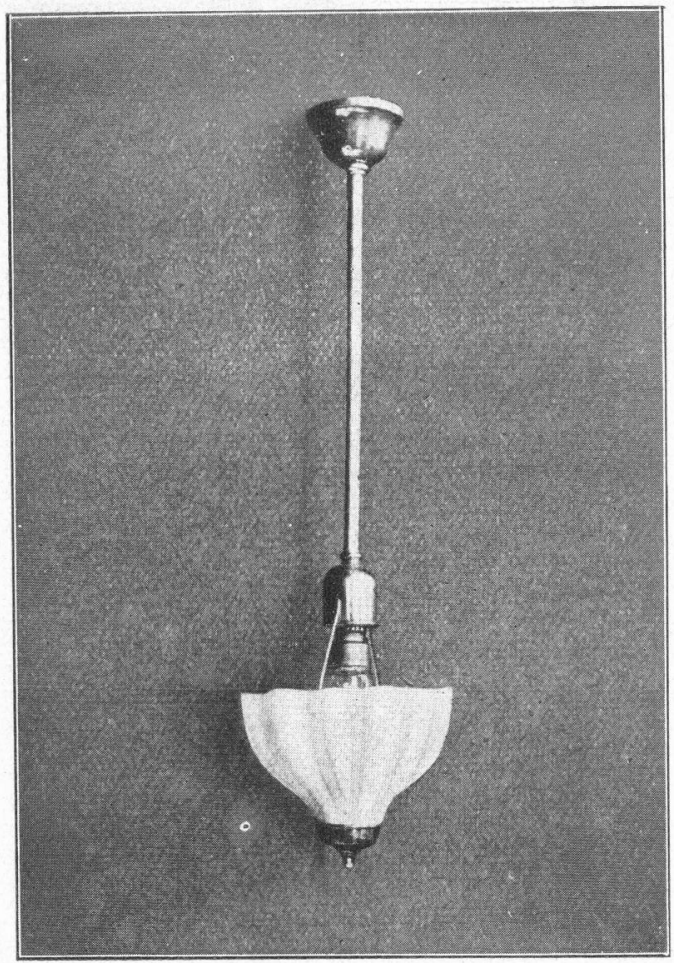

(210)

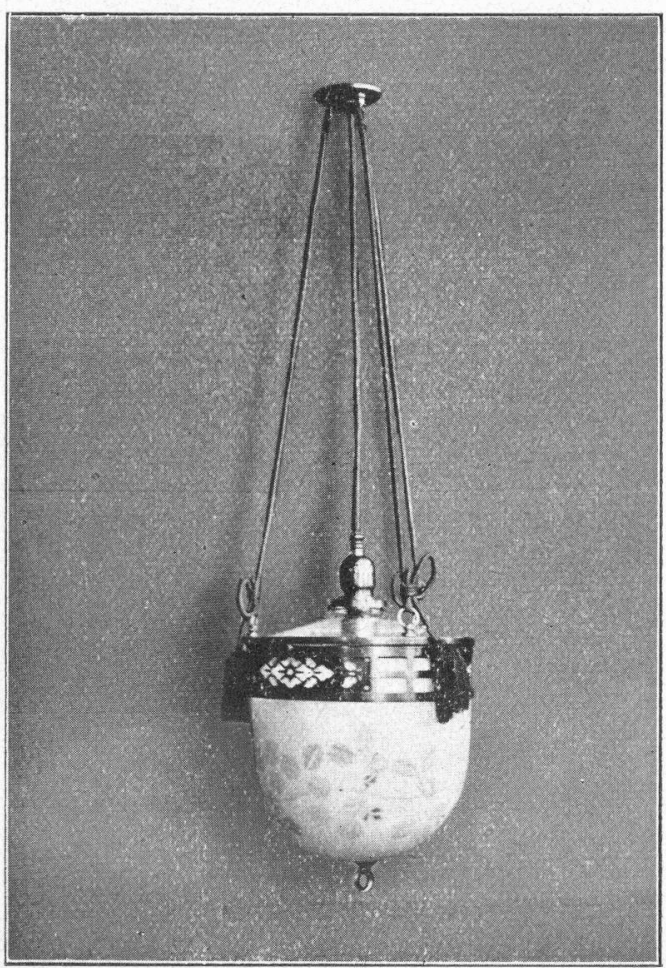

(209)

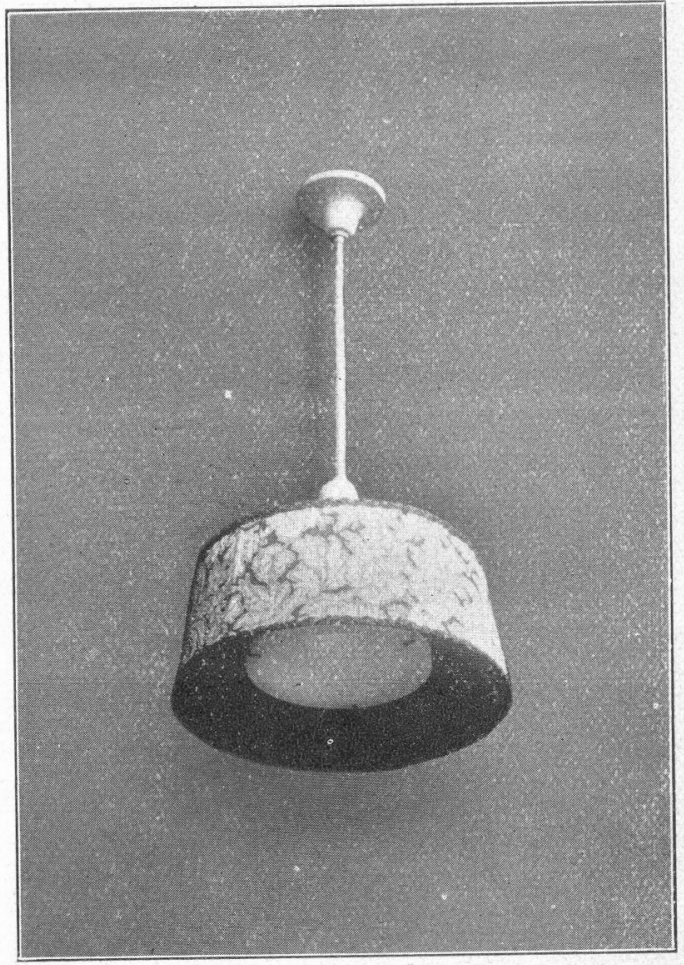

牛圍器具並室內用グローブ (301)

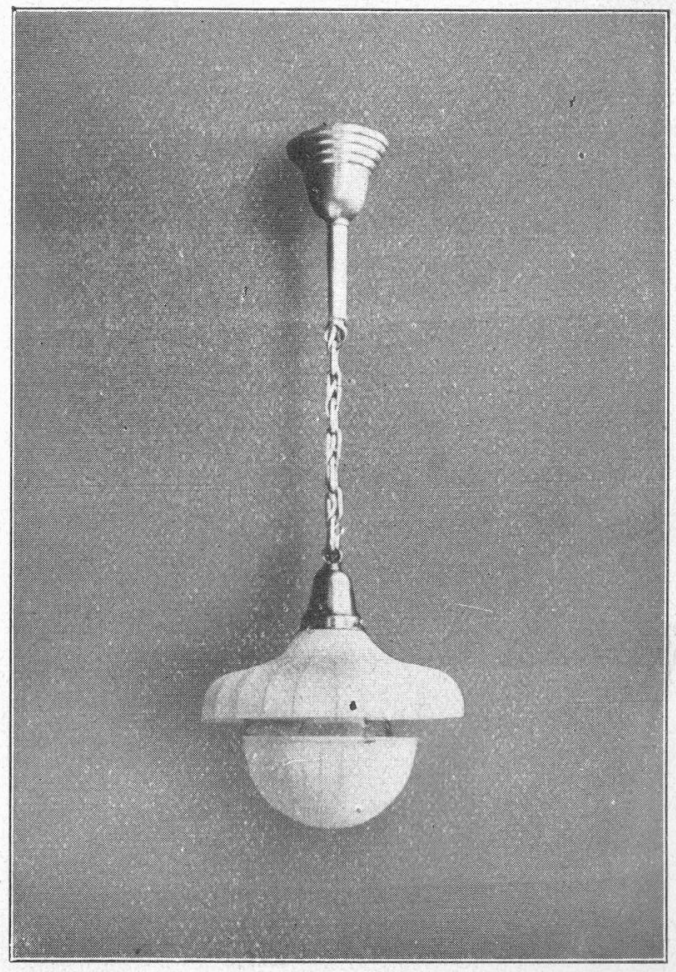


(304)

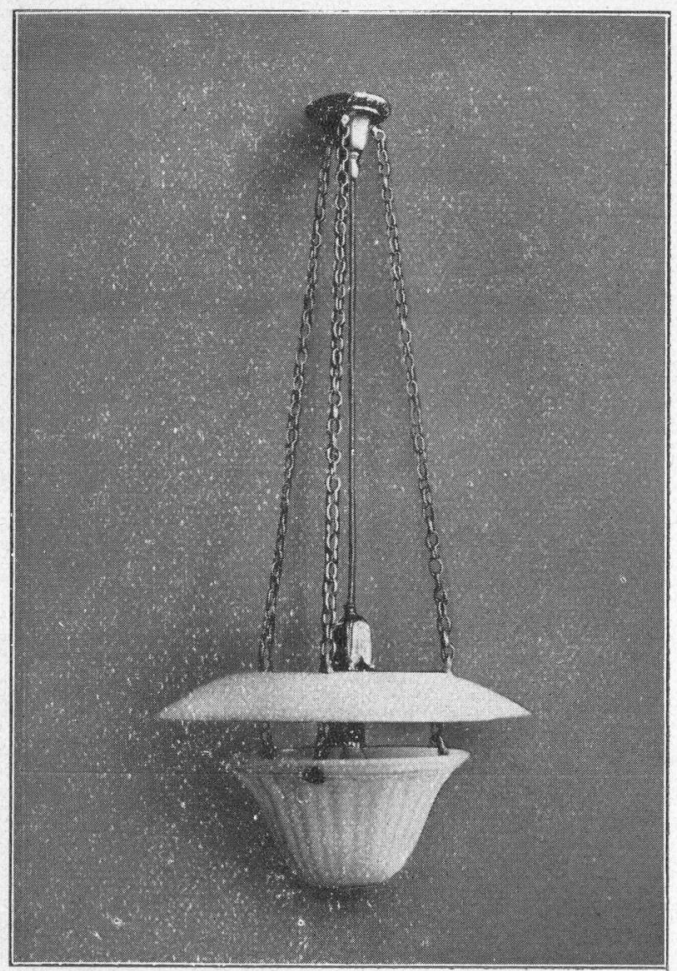

(306)

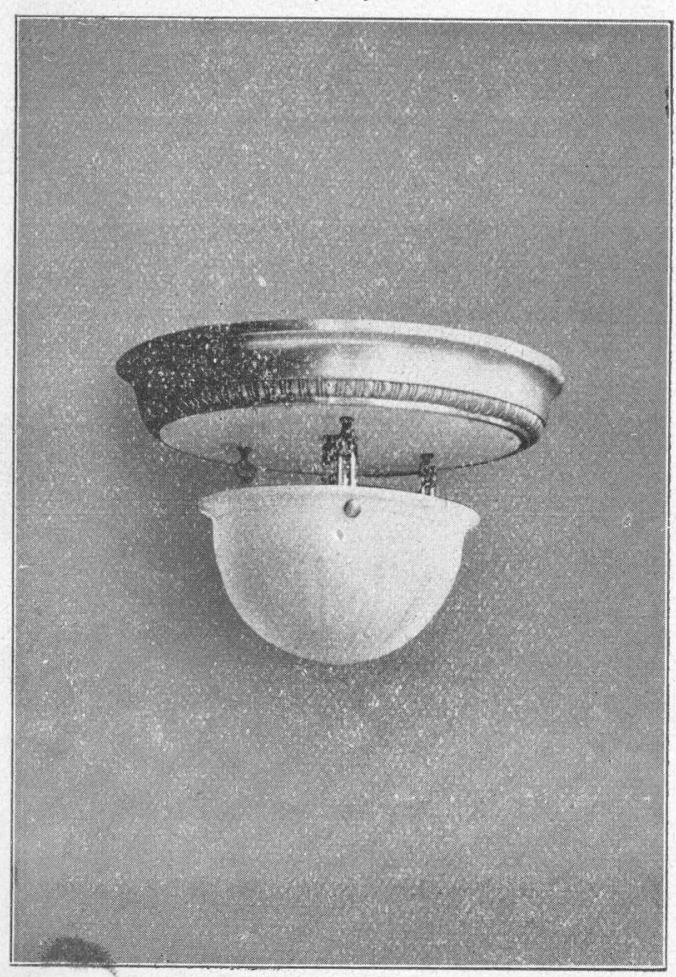

(305)

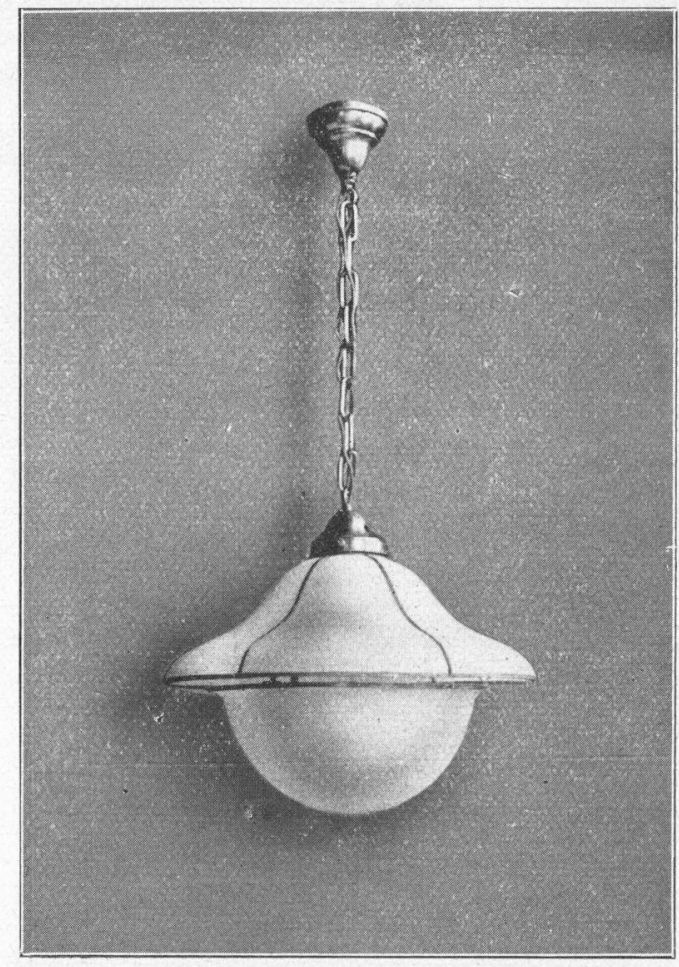

$(307)$

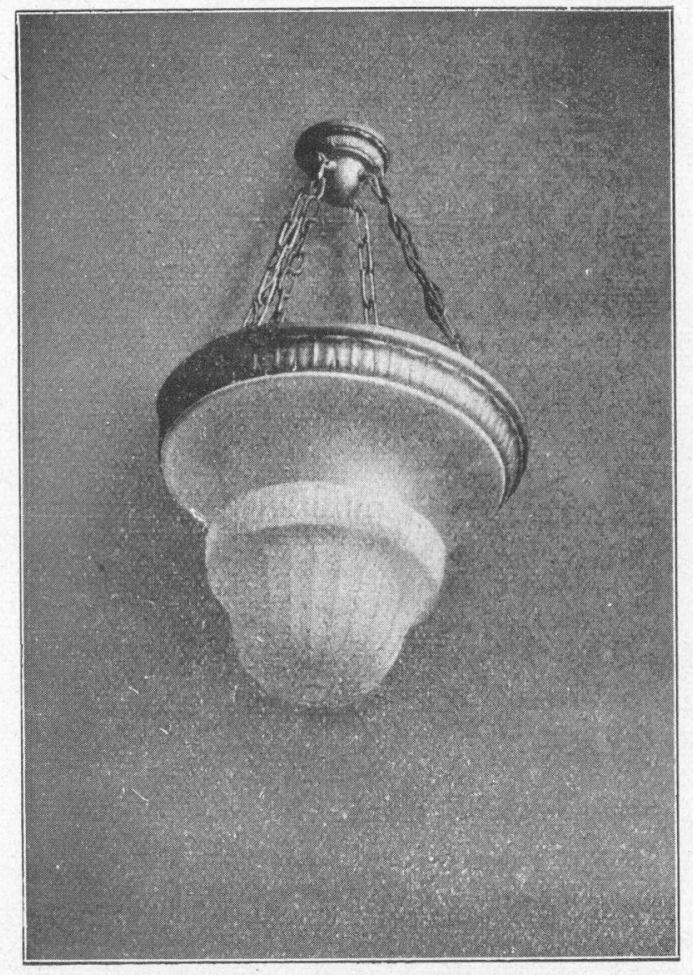

